\title{
Geochronological and thermochronological constraints on porphyry copper mineralization in the Domeyko alteration zone, northern Chile
}

\author{
Víctor Maksaev ${ }^{1}$, Tomás A. Almonacid ${ }^{2}$, Francisco Munizaga ${ }^{1}$, Víctor Valencia $^{3}$, \\ Michael McWilliams ${ }^{4}$, Fernando Barra ${ }^{3}$
}

\author{
${ }^{1}$ Departamento de Geología, Universidad de Chile, Casilla 13518, Correo 21, Santiago, Chile. \\ vmaksaev@ing.uchile.cl; fmunizag@ing.uchile.cl \\ ${ }^{2}$ Minera Peñoles de Perú S.A., Av. Central No. 643 Of. 201, San Isidro, Lima, Perú. \\ Tomas_Almonacid@penoles.com.mx \\ ${ }_{3}^{3}$ Department of Geosciences, University of Arizona, 1040 E. 4th Street, Bldg. \#77, Tucson, AZ 85721, USA. \\ victorv@email.arizona.edu; fbarra@email.arizona.edu \\ ${ }^{4}$ CSIRO Exploration and Mining, 26 Dick Perry Avenue, Kensington WA 6151, Australia; PO Box 1130, Bentley WA 6102, Australia. \\ Mike.Mcwilliams@csiro.au
}

\begin{abstract}
At Domeyko, $40 \mathrm{~km}$ south of Vallenar in northern Chile (28 $\left.57^{\prime} \mathrm{S}-70^{\circ} 53^{\prime} \mathrm{W}\right)$, the Dos Amigos and Tricolor porphyry copper centers are located within a north-south-elongated hydrothermal alteration zone $6 \times 1.5 \mathrm{~km}$ of surface dimensions. The centers are related to tonalite to granodiorite porphyry stocks displaying potassic alteration, which are surrounded by Lower Cretaceous andesitic volcanic rocks with sericitic, kaolinite-illite and propylitic alteration zones. The western boundary of the alteration zone is marked by the post-mineralization Cachiyuyo Batholith of granodioritic to dioritic composition. U-Pb zircon ages for the Dos Amigos porphyry are of 106.1 \pm 3.5 and 104.0 $\pm 3.5 \mathrm{Ma}$; and 108.5 \pm 3.4 for the nearby Tricolor porphyry. The Cachiyuyo Batholith yielded U-Pb zircon ages of 99.6 \pm 1.8 and 99.1 $\pm 1.9 \mathrm{Ma}$; and ${ }^{40} \mathrm{Ar} /{ }^{39} \mathrm{Ar}$ ages for biotite of $96.9 \pm 3.9$ and $94.8 \pm 0.9 \mathrm{Ma}$. These dates indicate that batholith emplacement postdated the Dos Amigos and Tricolor porphyries, in agreement with geological relationships. Although copper mineralization is spatially and genetically related to the Lower Cretaceous (Albian) porphyry stocks, most of the dated hydrothermal micas from the Dos Amigos and Tricolor porphyries yielded ${ }^{40} \mathrm{Ar} /{ }^{39} \mathrm{Ar}$ ages between $97.1 \pm 2.5$ and $96.0 \pm 1.4 \mathrm{Ma}$, which overlap within error with the cooling ages obtained for the neighboring batholith. ${ }^{40} \mathrm{Ar} /{ }^{39} \mathrm{Ar}$ dating of micas revealed significant disturbance of their K-Ar isotopic systematics that complicates accurate determination of the timing of hydrothermal activity at Domeyko. Nevertheless, the ${ }^{40} \mathrm{Ar} /{ }^{39} \mathrm{Ar}$ data establish a minimum Late Cretaceous age for this activity. A fission track age of $59.8 \pm 9.8 \mathrm{Ma}$ of apatite from the Dos Amigos porphyry indicates cooling through the temperature range of the apatite partial annealing zone $\left(\sim 125-60^{\circ} \mathrm{C}\right)$ during the Paleocene; and an $(\mathrm{U}-\mathrm{Th}) / \mathrm{He}$ age of 44.7 $\pm 3.7 \mathrm{Ma}$ of apatite from the same porphyry sample shows cooling through the temperature range of the apatite He partial retention zone $\left(\sim 85-40^{\circ} \mathrm{C}\right)$ during the Eocene. These ages correspond to the exhumation of the porphyry, and the latter provides a maximum age for the supergene enrichment processes that formed the chalcocite blanket currently mined at Dos Amigos.
\end{abstract}

Keywords: Porphyry copper, Andes, Chile, Geochronology, Thermochronology, Coastal Cordillera. 
RESUMEN. Determinaciones geocronológicas y termocronológicas para la mineralización de cobre porfídico en la zona de alteración de Domeyko, norte de Chile. En Domeyko, a $40 \mathrm{~km}$ al sur de la ciudad de Vallenar, en el norte de Chile ( $28^{\circ} 57^{\prime}$ S- $\left.70^{\circ} 53^{\prime} \mathrm{O}\right)$, se ubican los pórfidos cupríferos Dos Amigos y Tricolor dentro de una zona de alteración hidrotermal elongada en sentido norte-sur de $6 \times 1,5 \mathrm{~km}$. Estos están relacionados con stocks porfídicos tonalíticos a granodioríticos con alteración potásica, rodeados por zonas de alteraciones sericítica, caolinita-illita y propilítica, las cuales afectaron principalmente rocas volcánicas del Cretácico Inferior. El límite oeste de la zona de alteración lo constituye el Batolito Cachiyuyo postmineral de composición granodiorítica a diorítica. Edades U-Pb en circón para

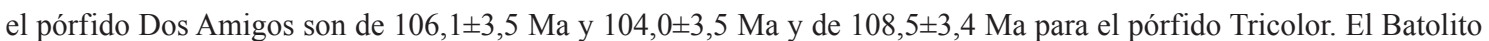
Cachiyuyo adyacente dio edades U-Pb en circón de 99,6 $\pm 1,9$ y 99, $1 \pm 1,9$ Ma y edades ${ }^{40} \mathrm{Ar} /{ }^{39} \mathrm{Ar}$ en biotita de $96,9 \pm 3,9$ y $94,8 \pm 0,9$ Ma. De acuerdo a estas edades el emplazamiento del batolito fue posterior a los pórfidos Dos Amigos y Tricolor, consistente con las relaciones geológicas. Aunque la mineralización de cobre está relacionada espacialmente y genéticamente con los stocks porfídicos del Cretácico Inferior (Albiano), la mayoría de las micas datadas de los pórfidos Dos Amigos y Tricolor dieron edades ${ }^{40} \mathrm{Ar} /{ }^{39} \mathrm{Ar}$ entre $97,1 \pm 2,5$ y 96,0 $\pm 1,4 \mathrm{Ma}$, las cuales son coincidentes con las edades de enfriamiento obtenidas para el batolito. La datación ${ }^{40} \mathrm{Ar} /{ }^{39} \mathrm{Ar}$ por pasos de micas reveló una importante perturbación del sistema isotópico K-Ar de las mismas, lo que complica una determinación exacta de la edad de la actividad hidrotermal en Domeyko, pero los datos ${ }^{40} \mathrm{Ar} /{ }^{39} \mathrm{Ar}$ establecen con certeza una edad mínima Cretácico Tardío para ella. Una edad de trazas de fisión en apatita de 59,8土9,8 Ma para el pórfido Dos Amigos indica enfriamiento a través del rango de temperatura de la zona de acortamiento parcial de trazas en apatita $\left(\sim 125-60^{\circ} \mathrm{C}\right)$ durante el Paleoceno y una edad (U-Th)/He en apatita de 44,7 3,7 Ma obtenida para el mismo pórfido revela enfriamiento a través del rango de la zona de retención parcial de $\mathrm{He}$ en apatita $\left(\sim 85-40^{\circ} \mathrm{C}\right)$ durante el Eoceno. Estas edades corresponden a la exhumación del pórfido y la última provee una edad máxima para los procesos de enriquecimiento supérgeno que formaron el nivel enriquecido con calcosina actualmente en explotación en la mina Dos Amigos.

Palabras clave: Pórfido cuprifero, Andes, Chile, Geocronología, Termocronología, Cordillera de la Costa.

\section{Introduction}

The Domeyko alteration zone is located in the southern part of the Atacama Desert, $40 \mathrm{~km}$ south of Vallenar (28०57'S-7053'W; Fig. 1). It includes the Dos Amigos porphyry copper deposit, currently being exploited, and the Tricolor porphyry copper occurrence (Fig. 2). Regionally, these deposits are part of a Mid-Late Cretaceous belt of porphyry copper deposits that extends along the eastern flank of the Coastal Cordillera of northern Chile, between latitudes $26^{\circ}$ and $31^{\circ} \mathrm{S}$ (Llaumett, 1975; Camus, 2002, 2003; Sillitoe and Perelló, 2005; Maksaev et al., 2006a, 2007) (Fig. 3).

The Domeyko alteration zone was first explored for its porphyry copper potential from 1962 to 1964, during a 'Program for Development' funded by the United Nations (Kents, $1962^{1}$ ), which detected copper mineralization occurrences at Tricolor and Dos Amigos (Fig. 2);

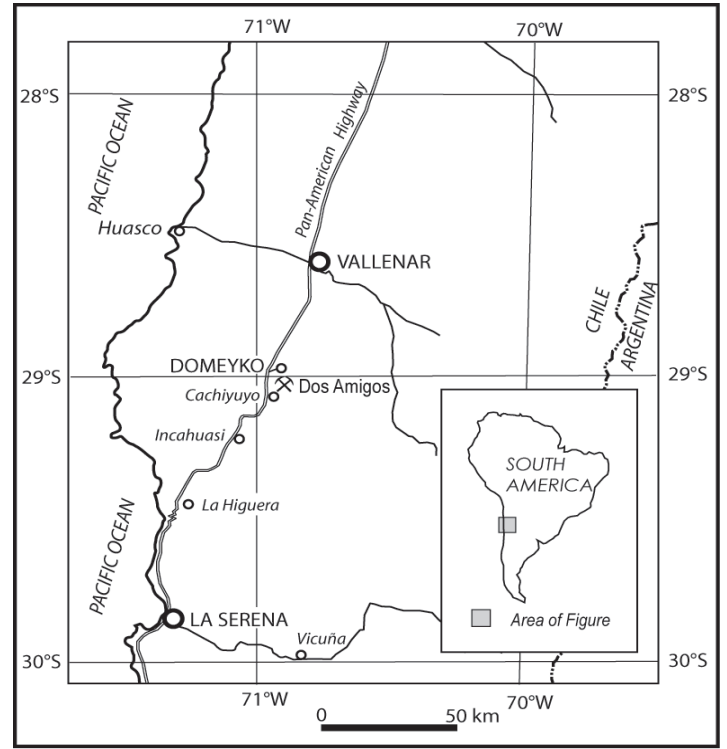

FIG. 1. Location map of Domeyko mining village and the Dos Amigos mine complex.

\footnotetext{
Kents, P. 1962. Domeyko hydrothermal development, Department Chañaral, Province of Atacama (unpublished report), United Nations Special Fund: 6 p.
} 


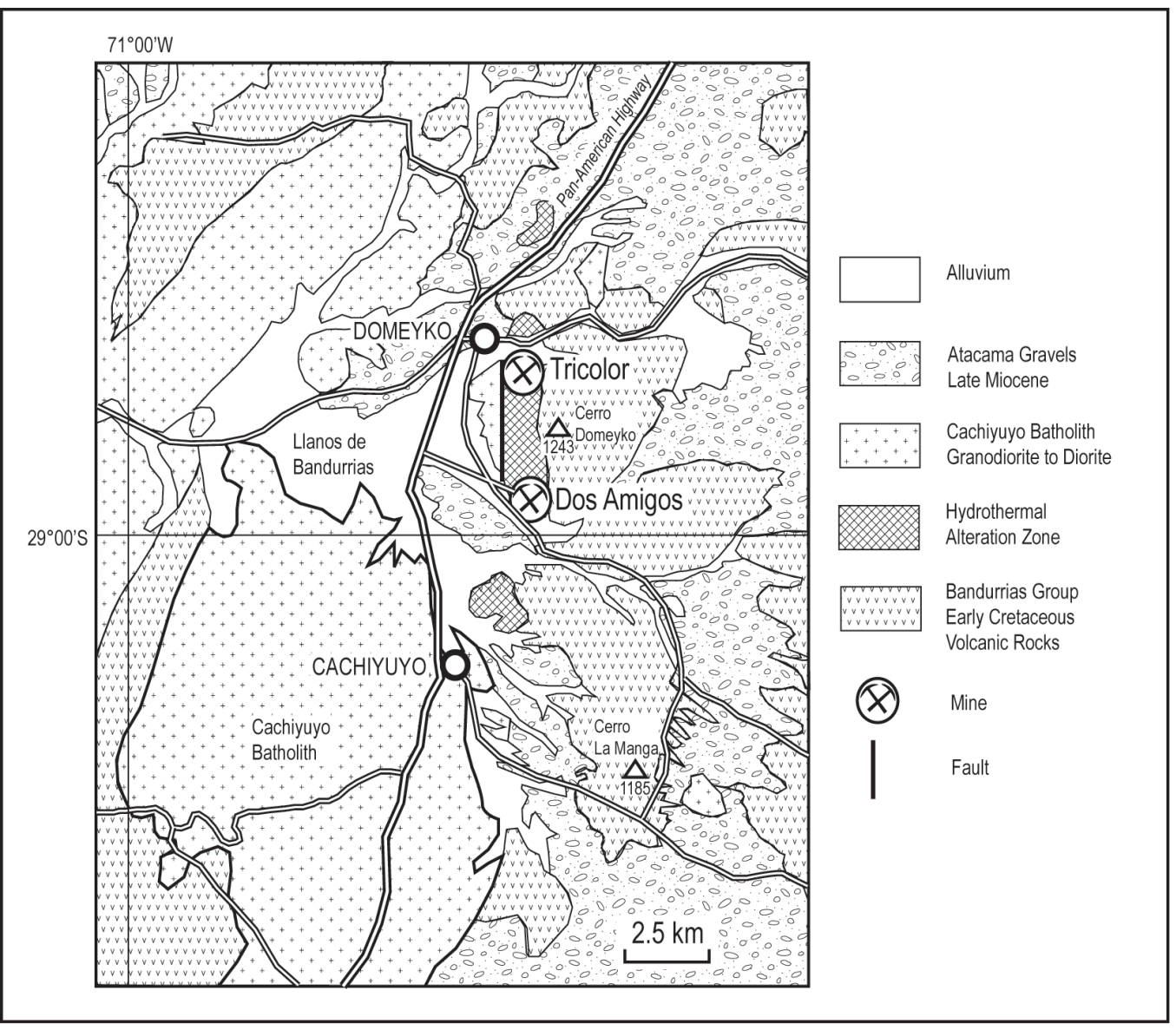

FIG. 2. Geological setting of the Domeyko alteration zone and the Dos Amigos and Tricolor porphyry copper centers. Regional geology modified after Moscoso et al. (1982).

six drill holes (totaling $683 \mathrm{~m}$ ) were completed at Tricolor intercepting low-grade hypogene copper intervals between 0.13 to 0.32 percent. It was followed by exploration during the years 1968 to 1971 by the governmental institution 'Corporación Nacional de Fomento' (CORFO) in the Dos Amigos area, including 43 diamond drill holes (totaling 5,361 $\mathrm{m}$ ) and 4 percussion drill holes $(236 \mathrm{~m})$. This program identified a supergene copper enrichment zone for which a resource of 3.5 million metric tons averaging 1.18 percent copper was estimated (Palafox, $1975^{2}$ ). Further exploration at Dos Amigos by Shell Chile between 1982 and 1983 expanded the supergene resource to 5 million metric tons at about 1 percent copper and 0.25 grams per metric ton gold and discovered additional hypogene mineralization of 36 million metric tons at 0.36 percent copper and 0.26 grams per ton gold. Since 1996, the enrichment blanket at Dos Amigos has been the objective of open pit mining by Compañía Explotadora de Minas (CEMIN), with annual average extraction of 1 million ton of ore averaging 1 percent copper, which is processed by heap leaching and solvent extraction-electrowinning (SX/EW) methods.

There are no previous publications on the geology of the Domeyko alteration zone, except for two whole rock K-Ar determinations of $106 \pm 10$ and $97 \pm 20 \mathrm{Ma}$ for altered rocks reported by Munizaga et al. (1985). Consequently, the present contribution constitutes the first geological

Palafox, L. 1975. 'María Soledad', Domeyko, Atacama, Chile. Property Examination Report (unpublished report), COMINCO Ltd. Exploration: $9 \mathrm{p}$. 


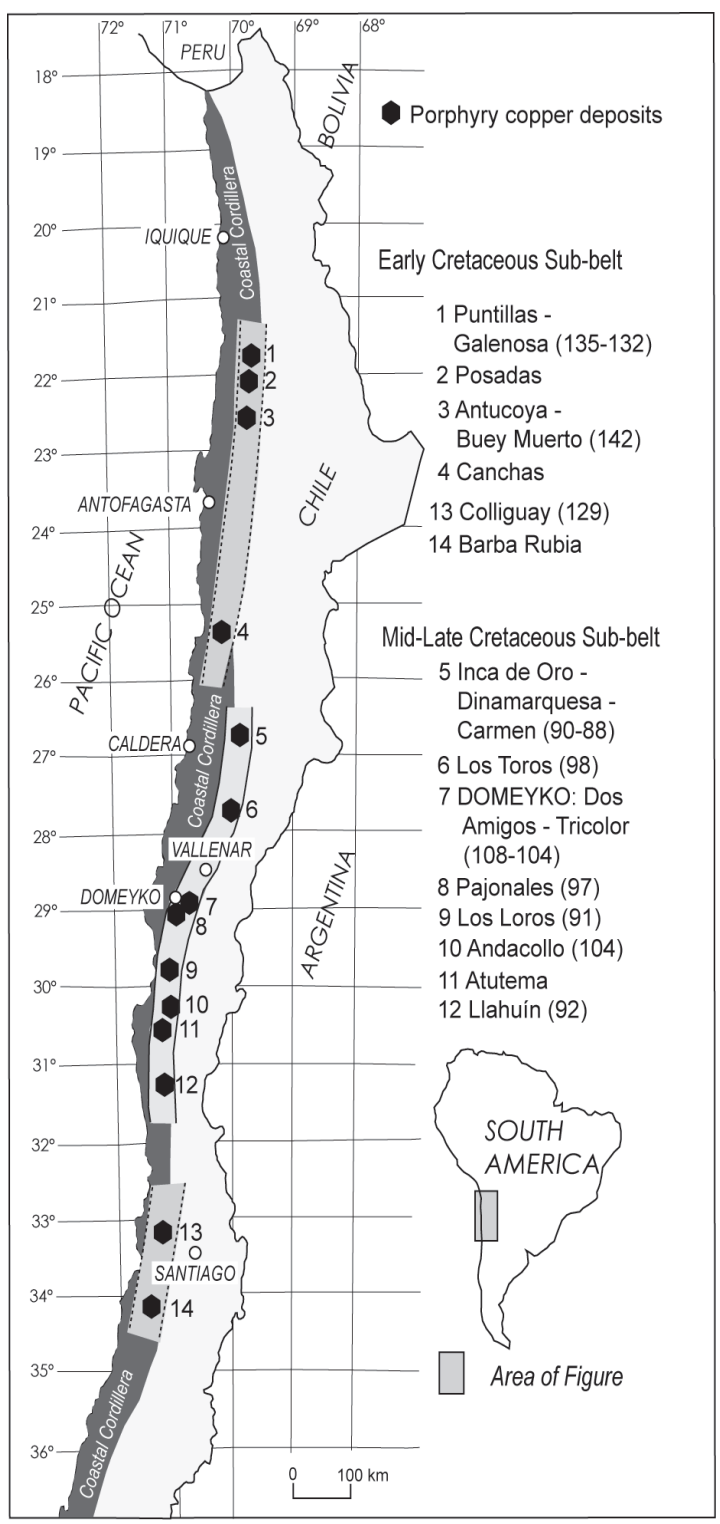

FIG. 3. The Cretaceous porphyry copper belt of northern Chile. Ages of deposits compiled from Camus (2003), Sillitoe and Perelló (2005) and Maksaev et al. (2006b).

description of the area. It provides new $\mathrm{U}-\mathrm{Pb}$, ${ }^{40} \mathrm{Ar} /{ }^{39} \mathrm{Ar}$, fission track and (U-Th) $/ \mathrm{He}$ data that confirm its position within a mid-Cretaceous metallogenic episode of porphyry copper mineralization (e.g., Sillitoe and Perelló, 2005). The present work also provides a time-temperature model for the low-temperature cooling of the Dos Amigos porphyry, which in turn helps to constrain the timing of the supergene processes and associated chalcocite enrichment.

\section{Metallogenic setting}

The porphyry copper belt that extends along the eastern flank of the Coastal Cordillera of northern Chile was initially recognized as the 'Pacific Belt' of Chilean porphyry copper deposits by Llaumett (1975). Subsequent geochronological work has shown that the porphyry copper systems located between latitudes $21^{\circ}$ and $23^{\circ} \mathrm{S}$ form a sub-belt with ages from 142 to $132 \mathrm{Ma}$ (Munizaga et al., 1985; Reyes, 1991; Boric et al., 1990; Perelló et al., 2003; Sillitoe and Perelló, 2005; Maksaev et al., 2006a); this belt seems to re-appear south of latitude $33^{\circ} \mathrm{S}$ (Fig. 3), but there are insufficient geochronological data to prove it. The porphyry copper deposits and prospects located in the Coastal Cordillera between latitudes $26^{\circ}$ and $31^{\circ} \mathrm{S}$ form another sub-belt with U-Pb ages from 108 to $88 \mathrm{Ma}$ (Maksaev et al., 2006b) (Fig. 3). The largest historic and current copper producer of the last sub-belt is the Andacollo porphyry copper-gold deposit (Llaumett et al., 1975; Reyes, 1991). It has been operated since 1996 by the Compañía Minera Carmen de Andacollo (ownership: 90\% Teck and 10\% 'Empresa Nacional de Minería'), with an average annual production of 21,000 tons cathode copper. Open pit mining at Andacollo to date has exclusively concentrated on leachable resources amounting to 34.6 million metric tons of 0.73 percent copper in the supergene chalcocite enrichment blanket, but its hypogene zone with resources of 311 million metric tons averaging 0.46 percent copper and 0.15 grams per ton gold is currently being prepared for production. In addition to the production at Dos Amigos deposit, a number of the other porphyry copper prospects from the sub-belt have been explored to varying degree, but have not attained production status (e.g., Los Toros, Los Loros; Fig. 3). In general, the Cretaceous porphyry deposits of the Coastal Cordillera are much smaller (resources $<\sim 300$ million metric tons) and possess lower hypogene grades $(<0.4 \%$ $\mathrm{Cu}$ ) than those of the Cenozoic porphyry copper belts located farther east and at higher elevations in the Chilean Andes (e.g., Sillitoe and Perelló, 2005). The Cretaceous deposits are related to small stocks of quartz diorite to granodiorite porphyry emplaced into arc-related plutonic and volcanic rocks. They tend to be dominated by potassic alteration (biotite, $\mathrm{K}$-feldspar) with a variably developed intermediate argillic overprint (illite, and/or smectite, chlorite, sericite). In addition, sericitic alteration is present at Andacollo, Antucoya-Buey Muerto, and in the 
Domeyko alteration zone (Reyes, 1991; Perelló et al., 2003; Maksaev et al., 2006a).

During the Jurassic to Early Cretaceous a subduction-related magmatic arc developed along the area of the Coastal Cordillera in westernmost Chile. The arc was flanked eastward (inland) by a sedimentary-marine back-arc basin represented by carbonate strata of the Chañarcillo Group (Segerstrom and Parker, 1959; Moscoso et al., 1982; Arévalo et al., 2005; Arévalo, 2005a, b). The porphyry copper sub-belt with U-Pb ages from 108 to 88 Ma extends along the eastern edge of this magmatic arc. The copper deposits were formed during and after the mid-Cretaceous (Albian) tectonic inversion of the back-arc basin, as shown by the end of marine sedimentation of the Chañarcillo Group and the onset of coarse-grained alluvial sedimentation and subaerial volcanism of the Cerrillos Formation during the late Aptian (e.g., Marschik and Fonboté, 2001; Marschik and Söllner, 2006; Charrier et al., 2007; Maksaev et al., 2009). This abrupt change in the sedimentary environment represents a significant modification of the tectonic regime on the continental margin from tensional to compressive (Maksaev et al., 2009), in turn related to a major reorganization of the Andean orogen involving the closure of the back-arc basins all along the western margin of South America (Dalziel, 1986; Bourgois et al., 1987; Mpodozis and Ramos, 1990).

This porphyry copper sub-belt runs parallel to, but some 10-15 km to the east of the 'Chilean Iron Belt' (Ruiz et al., 1965) made of a number of iron oxide-apatite and iron oxide-copper-gold deposits distributed along the southernmost segment $\left(26^{\circ}\right.$ $30^{\circ} \mathrm{S}$ ) of the Atacama Fault Zone (Fig. 4) (Ruiz et al., 1965; Espinoza, 1990; Nyström and Henríquez, 1994; Sillitoe, 2003; Gelcich et al., 2005; Maksaev et al., 2007). The Atacama Fault Zone is a major sinistral, strike-slip fault system that extends along the Coastal Cordillera for more than $1,000 \mathrm{~km}$ between latitudes $20^{\circ}$ and $30^{\circ}$ (Arabasz, 1971; Scheuber and González, 1999) (Fig. 4). It developed in the Jurassic with sinistral shear persisting into the Early Cretaceous in an overall transtensional tectonic setting along the magmatic arc, in close association with regional pluton emplacement, as well as crustal thinning and subsidence (Taylor et al., 1998; Brown et al., 1993; Dallmeyer et al., 1996; Scheuber and Andriessen, 1990; Scheuber et al., 1995; Scheuber and Gonzalez, 1999; Grocott and Taylor, 2002). K-Ar and ${ }^{40} \mathrm{Ar} /{ }^{39} \mathrm{Ar}$ ages for actinolite from magnetite-apatite deposits

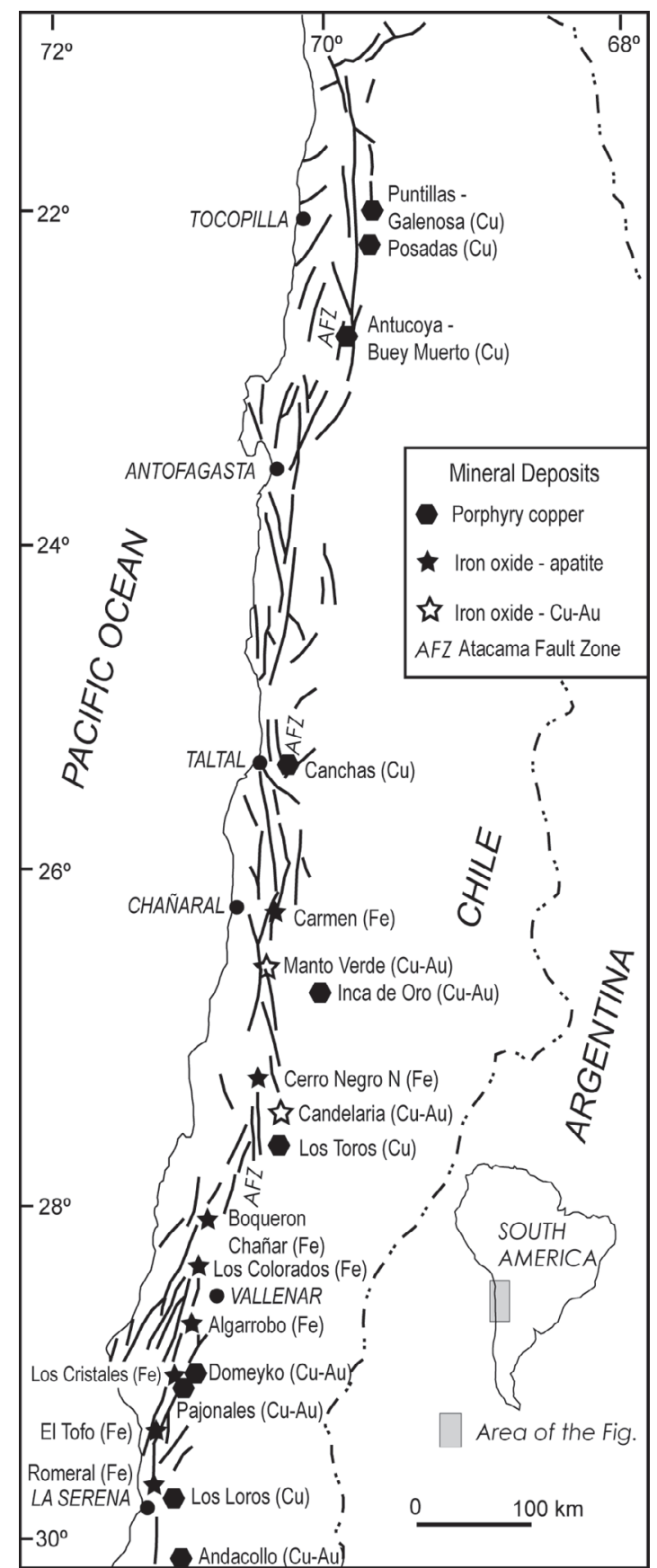

FIG. 4. The spatial relationship of the Cretaceous iron oxideapatite deposits of the Chilean Iron Belt, iron oxide copper-gold and the Lower Cretaceous porphyry copper deposits with major faults of the Atacama Fault Zone (AFZ) along the Coastal Cordillera of Northern Chile. Modified after Brown et al. (1993), Vila et al. (1996) and Maksaev and Zentilli (2002).

of 129 to 96 Ma have been published (e.g., Munizaga et al., 1985; Oyarzún et al., 2003; Díaz et al., 
2003) and suggest chronological overlapping with the 108 to 88 Ma range of the porphyry copper subbelt. However, older and more accurate U-Pb ages for magnetite and apatite from 131 to 127 Ma have also been reported for deposits of the Chilean Iron Belt (Gelcich et al., 2005). Therefore, the deposits of the Chilean Iron Belt represent a metallogenic episode that preceded in time the formation of the porphyry copper deposits. Whole-rock K-Ar ages of of $117 \pm 3$ and $121 \pm 3 \mathrm{Ma}$ for altered andesites and dykes at Manto Verde were initially taken to indicate the age of the primary mineralization of iron oxide-copper-gold deposits (Vila et al., 1996), but more precise $\mathrm{U}-\mathrm{Pb}$ ages of $128.9 \pm 0.6$ and $126.4 \pm 0.5$ $\mathrm{Ma}$ for a quartz monzonite to granodioritic dyke with potassic alteration, led Gelcich et al. (2003) to conclude that mineralization at Manto Verde is most probably even older. Likewise, dates older than those of the porphyry copper sub-belt have been reported for the Candelaria iron oxide-copper-gold deposit, including Re/Os molybdenite dates of $114.2 \pm 0.6$ and $115.2 \pm 0.6 \mathrm{Ma}$ interpreted as mineralization ages by Mathur et al. (2002). These are coincident with the $115.1 \pm 0.2 \mathrm{Ma}^{40} \mathrm{Ar}{ }^{39} \mathrm{Ar}$ plateau age for biotite associated with chalcopyrite-pyrite reported by Marschik and Fontboté (2001) and the ${ }^{40} \mathrm{Ar} /{ }^{39} \mathrm{Ar}$ plateau ages of $114.2 \pm 0.8$ and $114.1 \pm 0.7 \mathrm{Ma}$ for biotite of Ullrich \& Clark (1999). However, a younger ${ }^{40} \mathrm{Ar} /{ }^{39} \mathrm{Ar}$ plateau age of 111.7 $\pm 0.8 \mathrm{Ma}$ for amphibole (Ullrich and Clark, 1999) and similar ${ }^{40} \mathrm{Ar} /{ }^{39} \mathrm{Ar}$ ages of $111.0 \pm 1.7$ and 110.7 $\pm 1.6 \mathrm{Ma}$ for biotite (Arévalo et al., 2006) probably represent a later event of alteration at Candelaria, which overlaps within error with the oldest ages of the porphyry sub-belt. Thus, it is possible that mineralization at Candelaria represents a transition between iron oxide-copper-gold and porphyry copper metallogenic events during the mid-Cretaceous basin inversion along the Coastal Cordillera of northern Chile between latitudes $26^{\circ}$ and $31^{\circ} \mathrm{S}$.

\section{Local Geology}

The Domeyko alteration zone is located in a region characterized by rolling hills and intermontane depressions at an average elevation of $800 \mathrm{~m}$. It is exposed along a ridge that rises to $1243 \mathrm{~m}$ in elevation at the Domeyko hill, with dimensions of $6 \mathrm{~km}$ in the NS direction and 1 to $1.5 \mathrm{~km}$ in the EW direction (Fig. 2). The ridge stands above relics of extensive west-sloping terraces of Miocene gravels formed by coalescent alluvial fans, developed at elevations between 950 and $780 \mathrm{~m}$ (Atacama Gravels; Mortimer, 1973; Moscoso et al., 1982).

An unaltered, granodioritic to dioritic batholith (herein referred to as the Cachiyuyo Batholith) constitutes the abrupt western boundary of the Domeyko alteration zone. The batholith intruded the altered volcanic rocks, but its contact also coincides locally with a north-trending regional fault (Fig. 2). The majority of the altered rocks are part of a NNW-striking and E-dipping succession of Neocomian age assigned to the Bandurrias Group (Moscoso et al., 1982) and composed of andesitic lavas and volcanic breccias, with subordinate dacite. Minor intrusive bodies and dikes of finegrained, green-colored andesite are emplaced in the volcanic succession.

Two porphyry stocks intrude the volcanic rocks at Tricolor and Dos Amigos (Figs. 3 and 5). The Dos Amigos porphyry is tonalitic to granodioritic in composition with plagioclase and quartz phenocrysts, up to $4 \mathrm{~mm}$ in diameter, in a microcrystalline groundmass composed of an aggregate of plagioclase and quartz; some plagioclase phenocryst margins display vermicular intergrowths with $\mathrm{K}$-feldspar. The porphyry contains fine-grained hydrothermal biotite profusely disseminated and microcrystalline biotite aggregates replacing amphibole. The Tricolor porphyry is of similar composition with plagioclase and minor quartz phenocrysts in a microcrystalline groundmass composed of an aggregate of similar components. The porphyry contains abundant finegrained opaque minerals and hydrothermal biotite profusely disseminated; the latter typically altered to chlorite.

A composite hydrothermal breccia body (Marisol breccia) is exposed over a surface area of 500x600 m immediately north of the Dos Amigos mine (Fig. 5); its central part is polymictic and matrix-support-ed, with sericitically-altered angular fragments of volcanic rocks and porphyry in a matrix (30-40\%) of tourmaline and rock flour; abundant pyrite, but only minor chalcopyrite are visible in the breccia matrix in exploration adits. The marginal part of the Marisol breccia is formed by subrounded clasts of volcanic rocks in a matrix of silicified rock flour with sericite; underground this matrix includes pyrite. In an exploration adit $150 \mathrm{~m}$ beneath the surface, the breccia shows a higher proportion of strongly seriticized porphyry fragments in a matrix of tourmaline, pyrite, and quartz. 


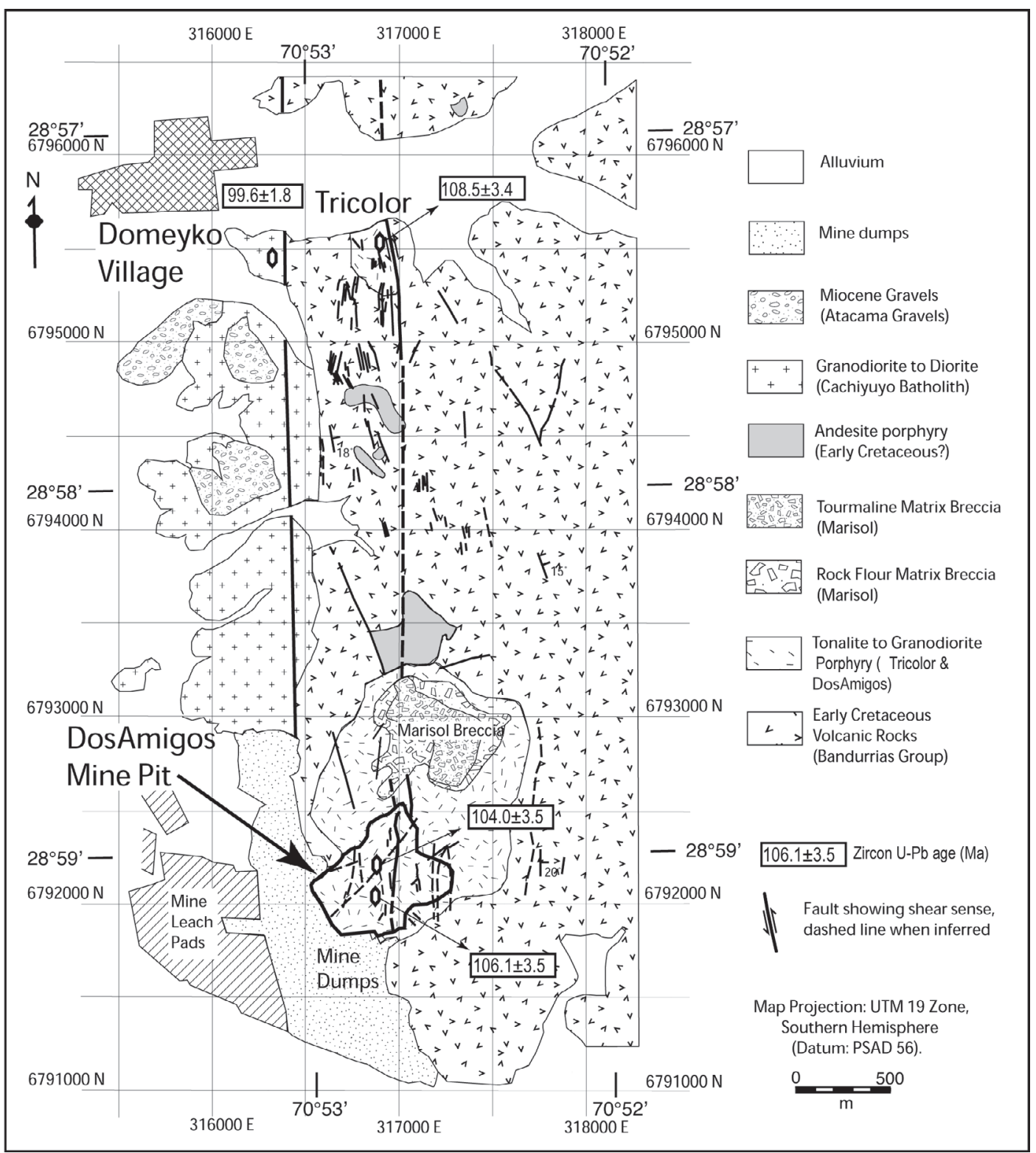

FIG. 5. Geological map of the Domeyko alteration zone showing the U-Pb zircon ages of intrusive rocks. Modified after Almonacid (2007).

A longitudinal fault zone traverses the whole altered area (Fig. 5), accompanied by a number of subsidiary northwest-trending subvertical faults; locally biotite-bearing porphyry is exposed at Tricolor with N-S/vertical foliation. The overall geometric fault pattern in the Domeyko alteration zone is compatible with a longitudinal sinistral shear (Almonacid, 2007).

\subsection{Alteration types}

The Domeyko alteration zone includes potassic, sericitic, kaolinite-illite, and propylitic alteration assemblages (Fig. 6). Potassic alteration is present at both Dos Amigos and Tricolor porphyries and in the immediately surrounding volcanic rocks east of Tricolor. The potassic zone at Dos Amigos is 


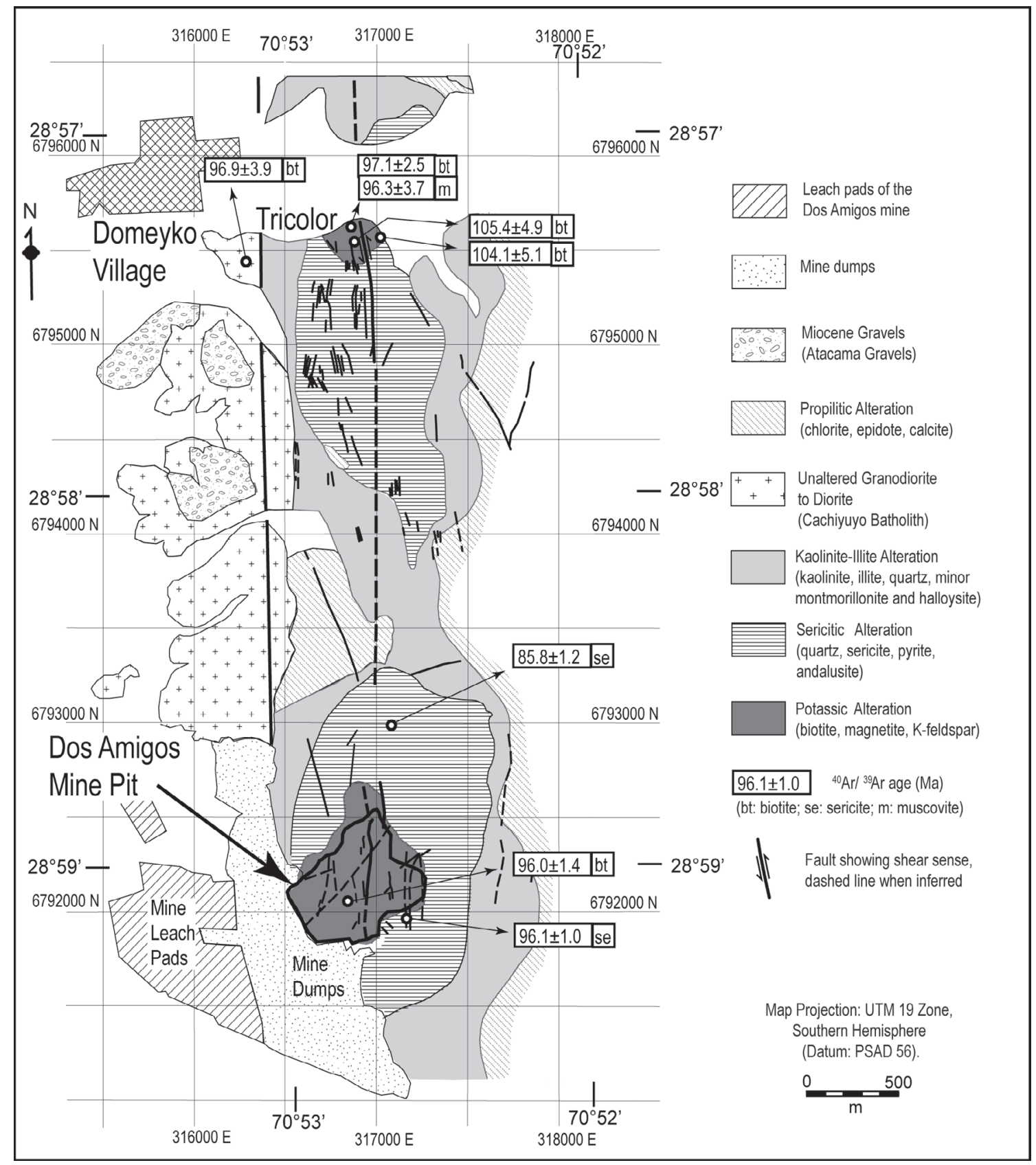

FIG. 6. Hydrothermal alteration map of the Domeyko alteration zone showing ${ }^{40} \mathrm{Ar} /{ }^{39} \mathrm{Ar}$ ages for micas. Modified after Almonacid (2007).

$750 \times 750 \mathrm{~m}$ in surface area, but that at Tricolor is only $250 \times 250 \mathrm{~m}$. The characteristic alteration mineral assemblage includes biotite and magnetite, with subordinate K-feldspar. The primary texture of the porphyries is largely preserved, but volcanic rocks adjacent to the porphyry at Tricolor are strongly bio- titized, black in color and show texture obliteration. Sericitic alteration surrounds both potassic alteration centers; it is characterized by bleaching of the rocks, almost complete destruction of original rock texture and an assemblage of quartz, fine-grained white mica, pyrite, and minor andalusite. The sericitic zones grade 
outward to rocks with preserved original texture, but with feldspars and mafic minerals altered to kaolinite, illite and quartz, with minor montmorillonite; this zone extends irregularly north-south for $\sim 5 \mathrm{~km}$. An external propylitic zone (chlorite, epidote and calcite) is mostly restricted to the eastern part of the Domeyko alteration zone (Fig. 6).

A supergene alteration overprint is apparent in most of the Domeyko alteration zone with common presence of halloysite and kaolinite, and fracture filling with supergene alunite and gypsum.

\subsection{Mineralization}

The Domeyko alteration zone exposes a leached cap characterized by the presence of profuse limonite staining and impregnation comprising goethite and hematite, which give an overall reddish color to the rocks of the area. This leached cap has an average thickness of $100 \mathrm{~m}$ over the Dos Amigos deposit and Marisol hydrothermal breccia body. A limited zone with oxidized copper minerals is preserved at the bottom of the leached cap at Dos Amigos; its thickness is irregular, ranging from a few meters to $\sim 30 \mathrm{~m}$ within fault zones. The main copper-bearing oxidized minerals are chrysocolla, atacamite and minor brochantite, which are accompanied by goethite and minor amarantite. At Tricolor a number of small shafts and adits along NNW and NW-trending fracture zones, from 0.3 to $1.2 \mathrm{~m}$ wide, contain chrysocolla and minor chalcocite.

A supergene chalcocite-enriched blanket is developed at Dos Amigos between 740 and $800 \mathrm{~m}$ elevation, with an average thickness of $\sim 30 \mathrm{~m}$ and up to $60 \mathrm{~m}$ in faults and fractured zones. Within this blanket black, sooty chalcocite has replaced the margins of pyrite and chalcopyrite grains. Minor covellite and digenite exist from the middle part to the bottom of the blanket, also mostly as fine coatings to pyrite, chalcopyrite and bornite, with covellite becoming increasingly abundant in the lowermost part of the enrichment zone. Although the supergene sulfides are largely restricted to rimming of the hypogene sulfides, the copper grade of the enrichment zone get to 1.25 percent, for an overall enrichment factor of up to 3 times the hypogene copper grade. However, the supergene enrichment within the Marisol hydrothermal breccia body averages copper grade of less than 0.5 percent, due to the lower hypogene grade of this unit $(0.2 \%$; Almonacid, 2007).
Hypogene copper-bearing minerals are mostly chalcopyrite and lesser bornite, within a stockwork of quartz veins hosted by the Dos Amigos porphyry displaying biotite-dominated potassic alteration exposed on the pit floor of the mine (740 m level); its vertical extent is currently unknown and copper grade typically averages less than 0.36 percent, according to CEMIN data. Irregular and discontinuous biotitic veins, 0.02 to $2 \mathrm{~mm}$ thick, are the earliest veins in the porphyry, and contain abundant magnetite, but lack sulfides. These veins are cut by wavy, irregular and discontinuous, quartz-bearing veins with biotite, 0.2 to $6 \mathrm{~mm}$ thick, which contain pyrite, chalcopyrite, bornite, and magnetite. Both vein sets are, in turn, cut by straight and continuous quartz-bearing veins; mostly composed of anhedral and euhedral quartz with either central or parallel bands of pyrite, chalcopyrite, and magnetite, together with minor bornite, biotite and sericite. Late veins are composed of pyrite, quartz and minor muscovite with sericitic alteration envelopes; only rare pyrite-chalcopyrite intergrowths exist in these late veins.

The potassic-altered tonalitic to granodioritic porphyry that crops out at Tricolor also displays a stockwork of sulfide-bearing quartz veins beneath the leach capping, which are apparent in the dumps of an exploration adit at $800 \mathrm{~m}$ elevation.

Gold mineralization at Dos Amigos and Tricolor is poorly constrained. However, limited surface sampling reveals anomalous values mostly less than 0.3 grams per ton (between 0.11 and $0.88 \mathrm{~g} / \mathrm{t} \mathrm{Au}$ ) for porphyries displaying potassic alteration; similarly, assays for 22 samples have returned average molybdenum values of only 15 parts per million (Almonacid, 2007).

\section{Geochronology}

\subsection{Analytical procedures}

\subsection{1. $U$-Pb dating}

Zircon grains from the Dos Amigos tonalite porphyry, the granodiorite porphyry of the Tricolor area, and the unaltered granodiorite and diorite of the Cachiyuyo Batholith were dated by LA-ICP-MS $\mathrm{U}-\mathrm{Pb}$. The new $\mathrm{U}-\mathrm{Pb}$ zircon geochronological results are summarized in Table 1, and are plotted with error bars $( \pm 2 \sigma)$ in figures 7 and 8 . The U-Pb analytical data are included in appendix A.

The analytical work was performed at the University of Arizona using the laser ablation ICP- 
TABLE 1. SUMMARY OF LA-ICP-MS ZIRCON U-Pb AGES AND SAMPLE LOCATION.

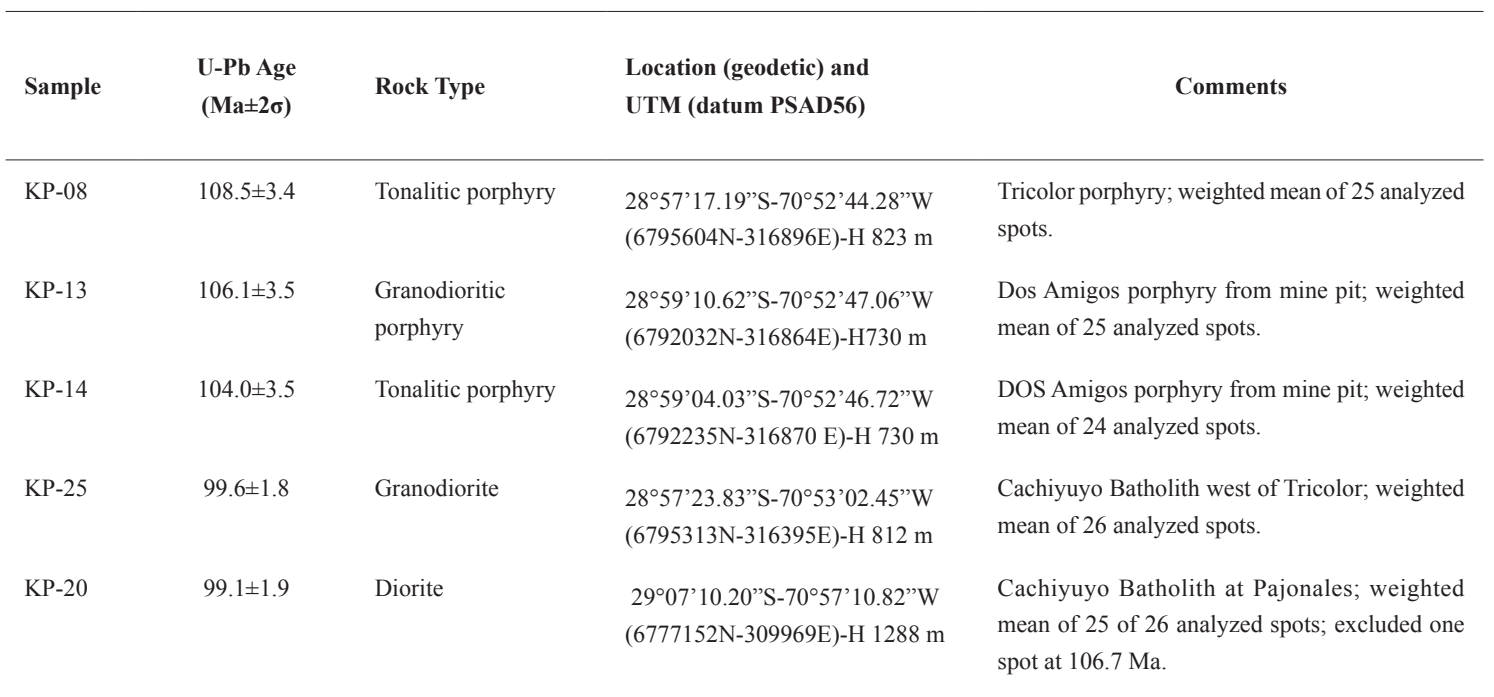

MS technique following procedures described by Gehrels et al. (2008) and Maksaev et al. (2009), who provided a detailed discussion of the samplepreparation techniques, analytical methods, and data analysis. The reported ages are based on ${ }^{206} \mathrm{~Pb} /{ }^{238} \mathrm{U}$ ratios because they are better constrained for young rocks than the ${ }^{207} \mathrm{~Pb} /{ }^{235} \mathrm{U}$ and ${ }^{206} \mathrm{~Pb} /{ }^{207} \mathrm{~Pb}$ ratios, which present significantly higher errors; all reported final ages and weighted mean ages have uncertainties at the two-sigma level.

\subsection{2. ${ }^{40} \mathrm{Ar} /{ }^{39} \mathrm{Ar}$ dating}

7 mica samples (biotite, muscovite, sericite) from the altered Dos Amigos and Tricolor porphyries and 2 biotite samples from the Cachiyuyo Batholith were dated by the step-heating ${ }^{40} \mathrm{Ar} /{ }^{39} \mathrm{Ar}$ method. The ${ }^{40} \mathrm{Ar} /{ }^{39} \mathrm{Ar}$ ages are summarized in Table 2 and the analytical data are included in appendix B. The analytical work was performed at the Stanford University using the step-heating technique following procedures of Marsh et al. (1997), who provided a detailed discussion of the sample-preparation techniques, analytical methods, and data analysis. Plateaus were defined using the criteria of Dalrymple and Lamphere (1971) and Fleck et al. (1977), specifying the presence of at least three contiguous gas fractions that together represent more than 50 percent of the total ${ }^{39} \mathrm{Ar}$ released from the sample and with apparent ages within error of each other. All
${ }^{40} \mathrm{Ar} /{ }^{39} \mathrm{Ar}$ plateau ages and weighted mean ${ }^{40} \mathrm{Ar} /{ }^{39} \mathrm{Ar}$ ages are reported with errors at the two-sigma level; besides, in order to avoid under-estimate analytical uncertainties, the errors have further been enhanced multiplying by (MSWD) $)^{1 / 2}$ for those weighted mean ages with a mean square of weighted deviates higher than 2 .

\subsubsection{Fission-track and (U-Th)/He dating}

Apatite from one sample of the Dos Amigos porphyry (KP-14) was dated by fission-track chronology at the laboratory of Apatite and Zircon Inc. (Viola, Idaho, USA) using laser ablation ICP-MS to estimate the uranium concentrations of the apatite grains for which spontaneous fission tracks were counted (e.g., Hasebe et al., 2004; Donelick et al., 2005); a summary of analytical data are included in appendix $\mathrm{C}$. The analysis included the measurement of the maximum fission-track etch-pit diameters oriented within $5^{\circ}$ of the $\mathrm{c}$ axis of the apatite crystal (Dpar) in order to consider fission-track annealing variability among different apatite species in thermal history modeling (Carlson et al., 1999). Irradiation of the apatite sample with ${ }^{252} \mathrm{Cf}$ was used to increase the amount of etched confined track for length measurement. The AFTSolve multi-kinetic inverse modelling program of apatite fission track data (Ketcham et al., 2000) was used to derive timetemperature history for the Dos Amigos porphyry from the apatite fission-track data. This program 

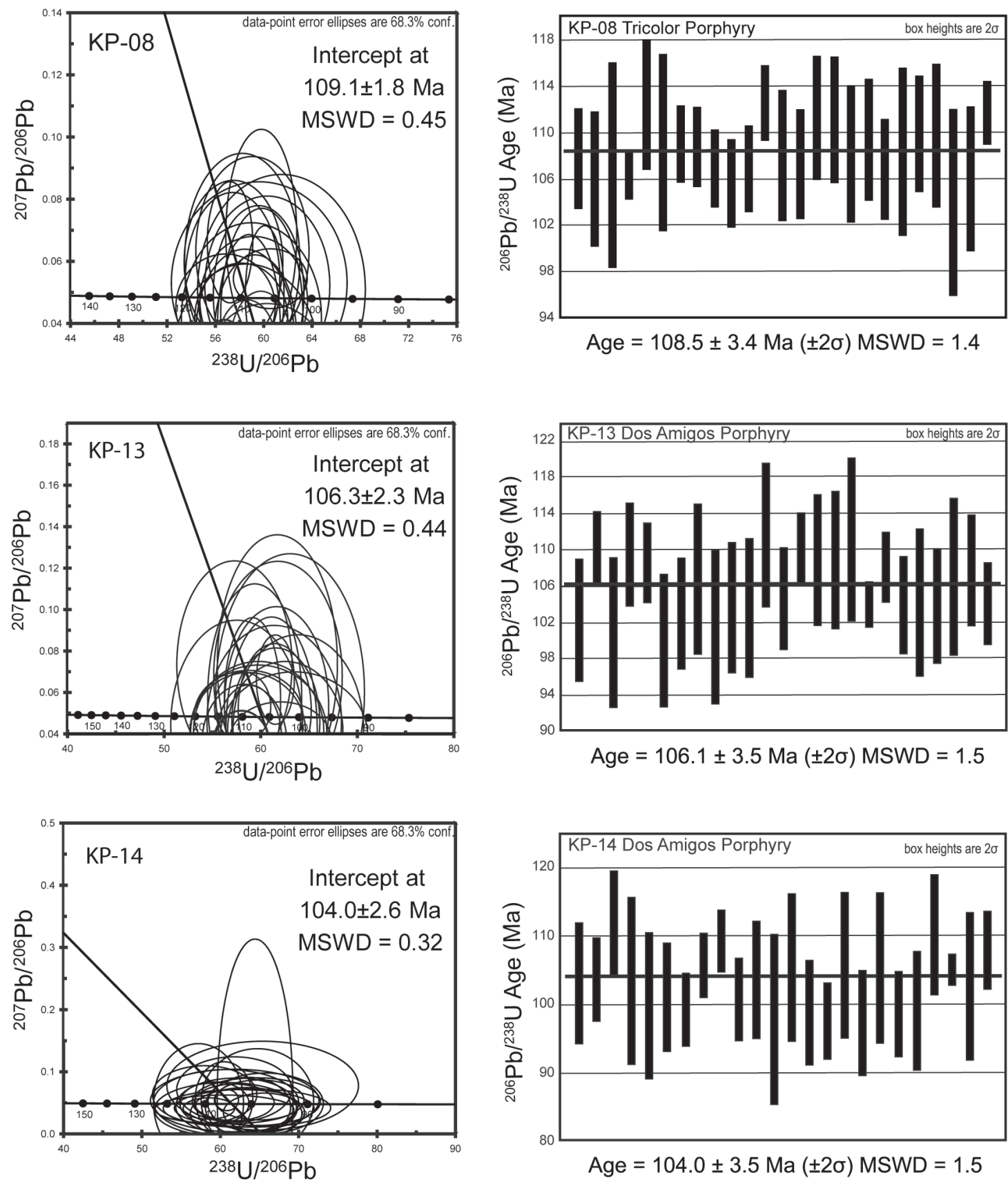

FIG. 7. Plot of U-Pb zircon ages for individual LA-ICP-MS analyses from samples KP-08, KP-13 and KP-14 from mineralized Tricolor and Dos Amigos porphyries. The thick line shows the respective weighted average age (error bars are at $\pm 2 \sigma$ ). As a reference, Tera-Wasserburg plots of the U-Pb data with ellipses at $\pm 1 \sigma$ are shown.

implements various laboratory calibrations of the behavior of fission tracks in apatite in response to heating and cooling histories, and calculates the range of thermal histories that are potentially consistent with the measured age and the measured frequency distribution of confined track lengths.
Full details concerning these calibrations and the various uses of AFTsolve are given in Carlson et al. (1999), Donelick et al. (1999), Ketcham et al. (1999, 2000). 20,000 random time-temperature paths are created by a Monte Carlo scheme, and for each path the resulting fission-track age and track length 

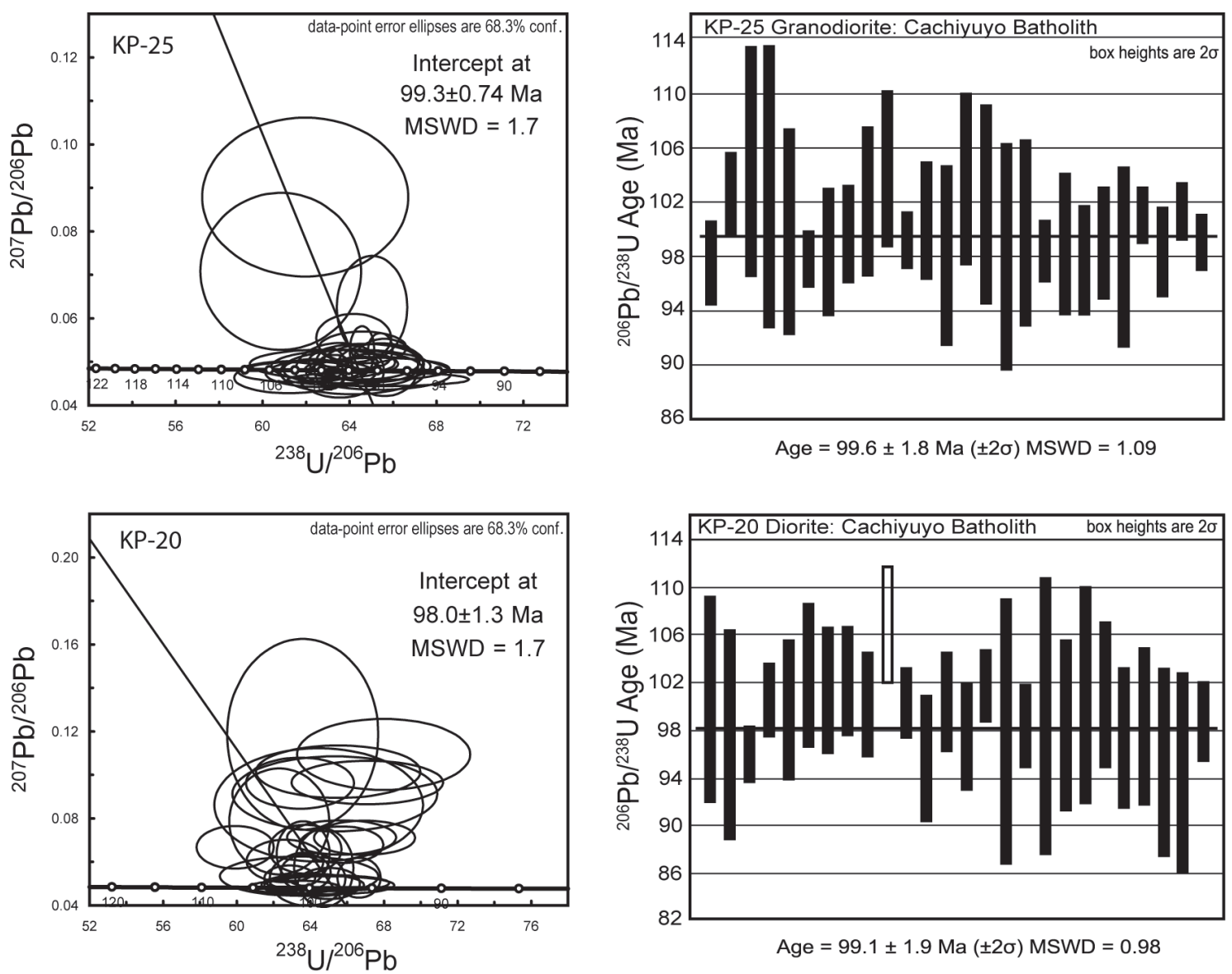

FIG. 8. Plot of U-Pb zircon ages for individual LA-ICP-MS analyses from samples KP-25 and KP-20 from the unaltered Cachiyuyo Batholith. The thick line shows the respective weighted average age (the unshaded bar was excluded from age calculation; error bars are at $\pm 2 \sigma$ ). As a reference, Tera-Wasserburg plots of the U-Pb data with ellipses at $\pm 1 \sigma$ are shown.

distribution are calculated, and the goodness-of-fit between calculated and measured data is evaluated by a Kolmogorov-Smirnov test. The program maps out the time-temperature regions that envelop all thermal histories with 'good' and 'acceptable' fit, corresponding to goodness-of-fit values from 0.5 to 1 and from 0.05 to 0.5 , respectively.

Apatite from the same sample (KP-14) from the Dos Amigos porphyry was also dated by the (U-Th)/He method at Stanford University by argon laser heating for He extraction and at UC Santa Cruz by sector ICP-MS for U-Th determinations; an analytical uncertainty of 7 percent is estimated for the apatite analyses; the analytical data are included in appendix C. Replicate analyses yielded concordant ages and the final (U-Th)/He ages reported include an alpha-ejection correction that accounts for diffusion-domain-dependent loss of the daughter nuclide (after Farley et al., 1996 and Farley, 2002).

\subsection{Results}

\subsection{1. $\mathrm{U}$-Pb dating}

Two samples from the potassic-altered, mineralized porphyry, collected at the bottom of the open pit in the Dos Amigos mine (KP-13, KP-14; Fig. 5), yielded U-Pb ages of $106.1 \pm 3.5$ and $104.0 \pm 3.5 \mathrm{Ma}$, respectively. In addition, a sample from the Tricolor porphyry (KP-08) also potassic-altered yielded a U-Pb age of 108.5 $\pm 3.4 \mathrm{Ma}$ (Figs. 5 and 7). These ages are indistinguishable from each other, as they overlap within analytical error; they correspond to the Albian according to the International Stratigraphic Chart, 2008. 
TABLE 2. SUMMARY OF ${ }^{40} \mathrm{Ar} /{ }^{39} \mathrm{Ar}$ STEP-HEATING AGES.

a. ${ }^{40} \mathrm{Ar} /{ }^{39} \mathrm{Ar}$ step-heating ages that defined a plateau ( $>50 \%$ of released gas).

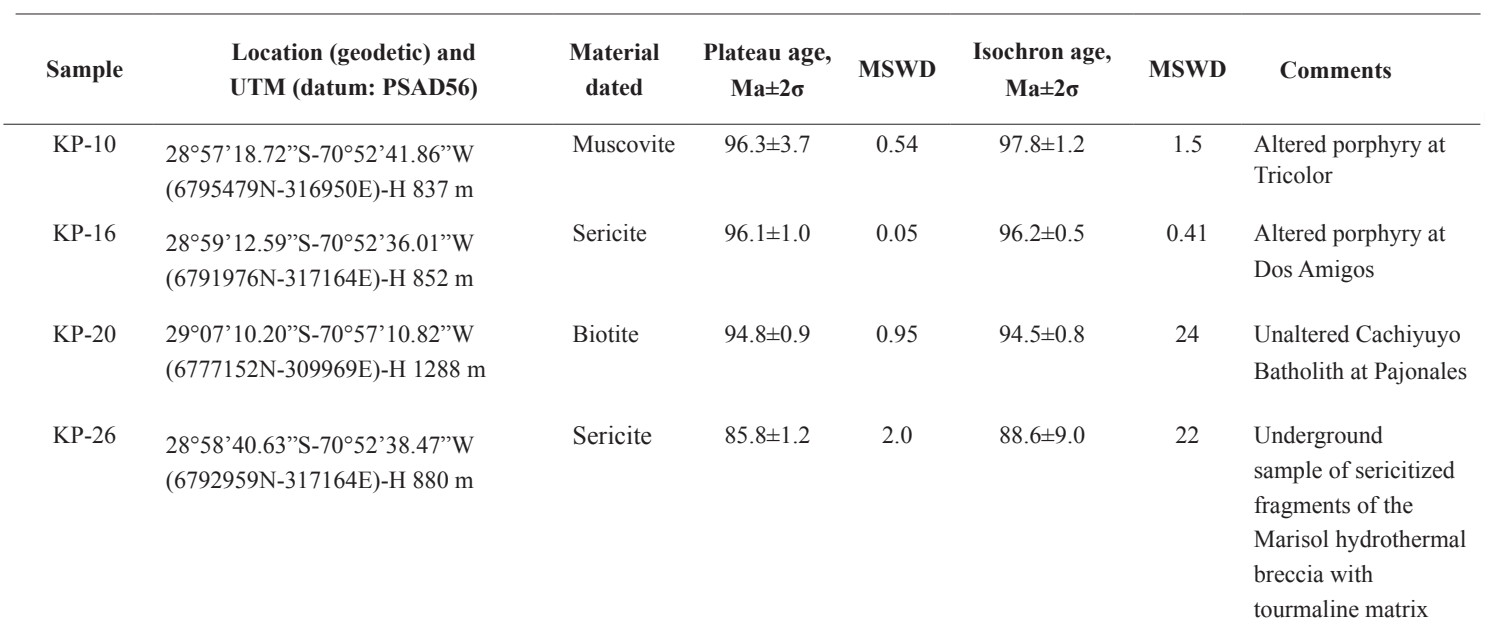

b. ${ }^{40} \mathrm{Ar} /{ }^{39} \mathrm{Ar}$ step-heating ages with irregular age spectra (MSWD $>2$ ).

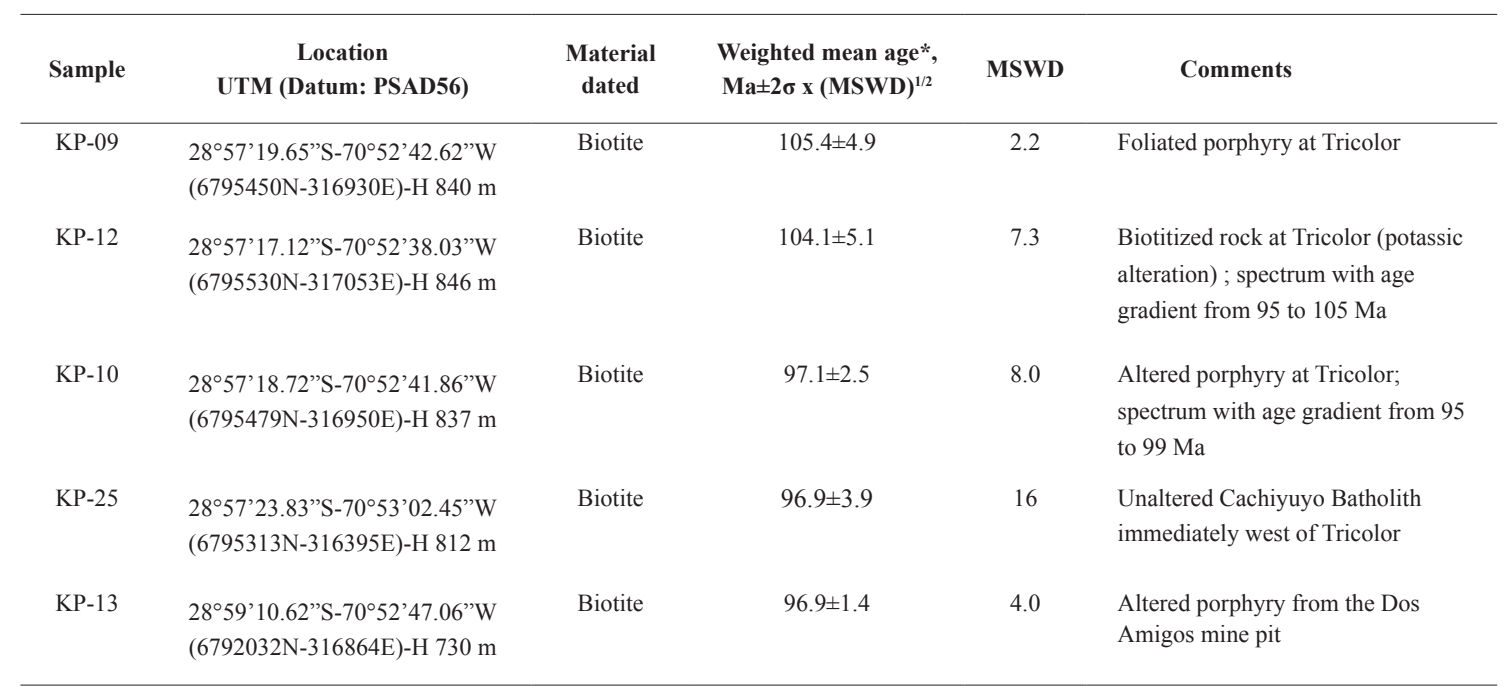

- The error of these ages has been enhanced multiplying by (MSWD) ${ }^{1 / 2}$ due to the dispersion of apparent ages of the selected steps.

A sample of granodiorite from the Cachiyuyo Batholith immediately west of Tricolor (KP-25) yielded a $\mathrm{U}-\mathrm{Pb}$ age of $99.6 \pm 1.8 \mathrm{Ma}$ (Fig. 5) and a diorite sample from the same batholith, but collected $19 \mathrm{~km}$ to the southwest (KP-20) yielded an indistinguishable $\mathrm{U}-\mathrm{Pb}$ age of $99.1 \pm 1.9$ Ma (Fig. 8).

\subsection{2. ${ }^{40} \mathrm{Ar} /{ }^{39} \mathrm{Ar}$ dating}

Most of the age spectra obtained are irregular implying disturbance of the K-Ar isotopic system of the dated micas (Figs. 9 and 10). Only four age spectra define plateaus with at least 50 percent of the released argon and with apparent ages within error of each other (Table 2a). The samples from the 

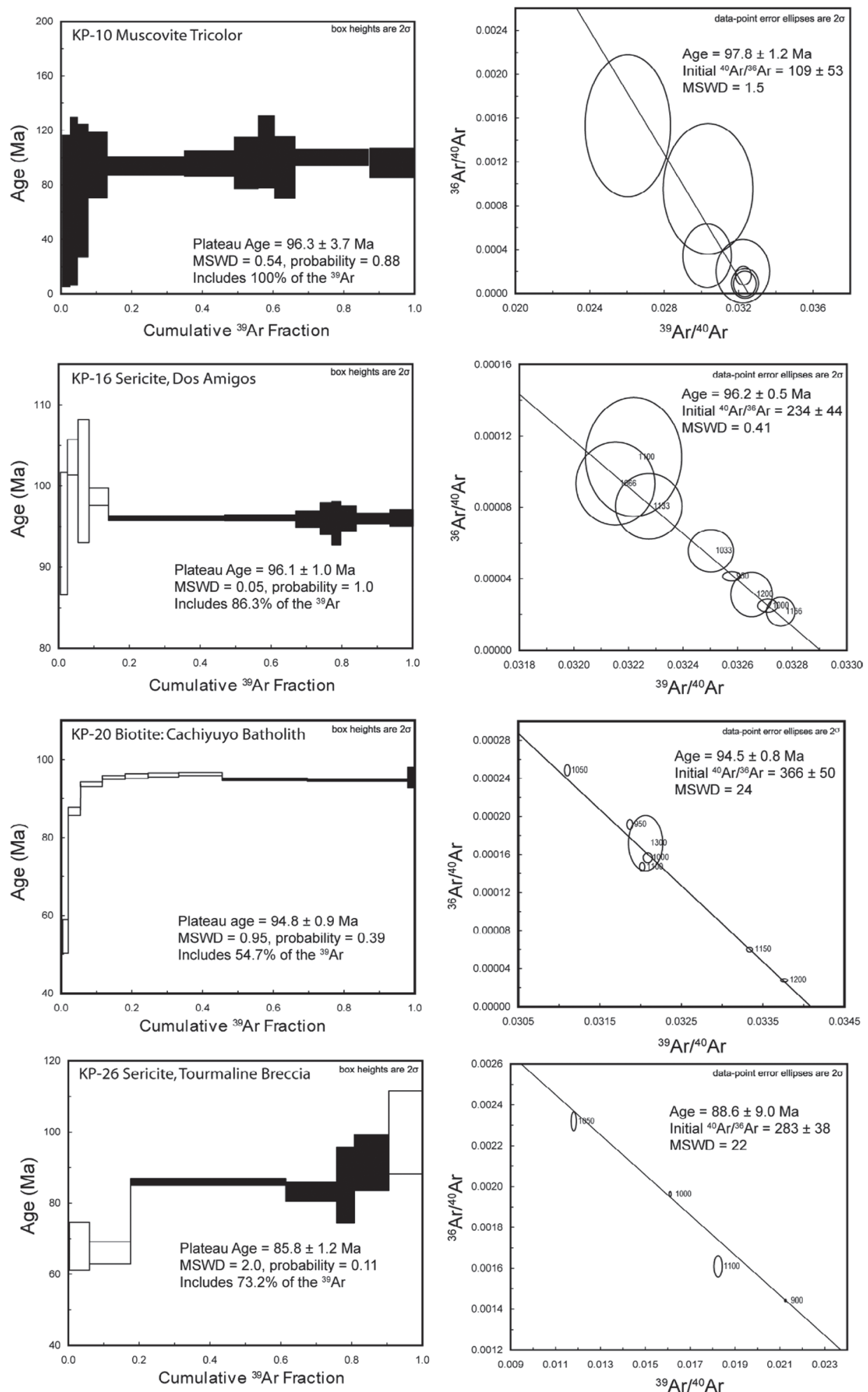

FIG. 9. Apparent ${ }^{40} \mathrm{Ar} /{ }^{39} \mathrm{Ar}$ age spectra and inverse isochrons for samples that defined plateaus from the Domeyko alteration zone and the Cachiyuyo Batholith. The black boxes indicate the steps used to derive the respective plateau ${ }^{40} \mathrm{Ar}{ }^{39} \mathrm{Ar}$ ages. 

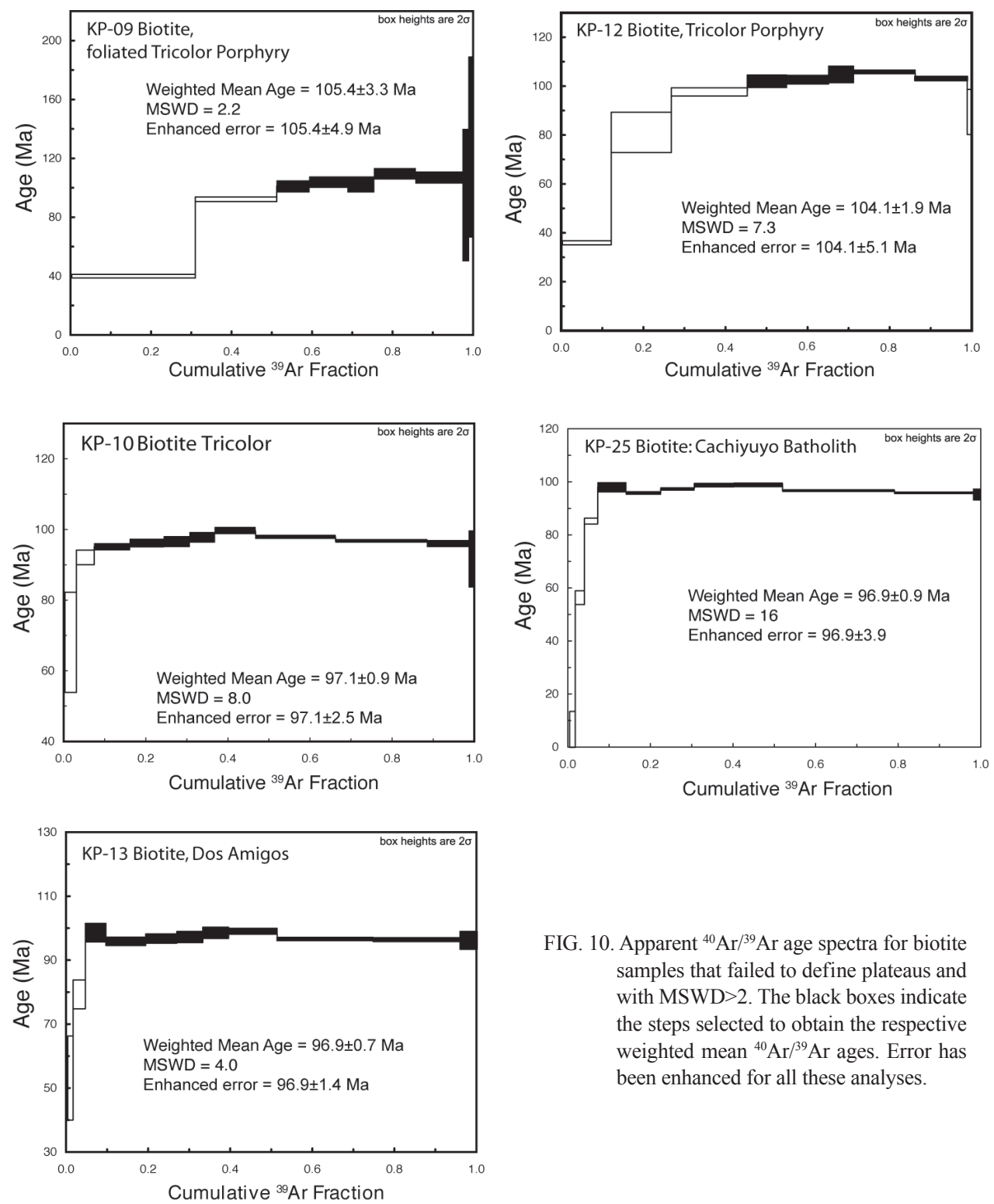

FIG. 10. Apparent ${ }^{40} \mathrm{Ar} /{ }^{39} \mathrm{Ar}$ age spectra for biotite samples that failed to define plateaus and with MSWD $>2$. The black boxes indicate the steps selected to obtain the respective weighted mean ${ }^{40} \mathrm{Ar} /{ }^{39} \mathrm{Ar}$ ages. Error has been enhanced for all these analyses.

Domeyko alteration zone yielded ${ }^{40} \mathrm{Ar} /{ }^{39} \mathrm{Ar}$ plateau ages for sericite and muscovite from $96.3 \pm 3.7$ to $85.8 \pm 1.2 \mathrm{Ma}$, and a ${ }^{40} \mathrm{Ar}{ }^{39} \mathrm{Ar}$ plateau age of $94.8 \pm 0.9$ Ma was obtained for biotite from the Cachiyuyo batholith (Table 2a; Fig. 9). Yet, the ${ }^{40} \mathrm{Ar} /{ }^{39} \mathrm{Ar}$ plateau ages of $96.3 \pm 3.7$ and $96.1 \pm 1.0 \mathrm{Ma}$ for muscovite and sericite from the altered porphyry stocks (KP10, KP-16; Table 2a) are much younger than their respective $\mathrm{U}-\mathrm{Pb}$ ages of $108.5 \pm 3.4$ and $106.1 \pm 3.5$ $\mathrm{Ma}$, and the ${ }^{40} \mathrm{Ar} /{ }^{39} \mathrm{Ar}$ plateau age of $94.8 \pm 0.9 \mathrm{Ma}$ obtained for biotite from the batholith (KP-20) is also younger than its $\mathrm{U}-\mathrm{Pb}$ age of $99.1 \pm 1.9 \mathrm{Ma}$.

Thus, these ${ }^{40} \mathrm{Ar} /{ }^{39} \mathrm{Ar}$ plateaus represent minimum cooling ages; in fact, some of the spectra (KP-10, KP-16) have relatively large errors of the apparent ages of individual steps and their respective inverse isochrons show initial ${ }^{40} \mathrm{Ar} /{ }^{36} \mathrm{Ar}$ ratios lower than the 295.5 value of atmospheric argon, which is consistent with argon loss (Fig. 9). The youngest ${ }^{40} \mathrm{Ar} /{ }^{39} \mathrm{Ar}$ plateau age of $85.8 \pm 1.2 \mathrm{Ma}$ for sericite from the Marisol tourmaline breccia probably reflect argon loss as well.

The remaining five biotite samples show significant disparity in their apparent ages of individual 
degassing steps, even for selected portions of the respective age spectra (MSWD>2; Fig. 10). Therefore, their analytical uncertainty has been enhanced yielding weighted mean ${ }^{40} \mathrm{Ar} /{ }^{39} \mathrm{Ar}$ ages from $105.4 \pm 4.9$ to $96.9 \pm 1.4 \mathrm{Ma}$ (Table $2 \mathrm{~b}$ ). Despite of disturbance and imprecision these ages for biotite overlap within error with the U-Pb dates that were obtained for the Domeyko alteration zone and the Cachiyuyo Batholith (Fig. 11).

\subsubsection{Fission-track and (U-Th)/He thermochronology}

Sample KP-14 from the Dos Amigos porphyry yielded a LA-ICP-MS apatite fission-track age of $59.8 \pm 9.8 \mathrm{Ma}( \pm 2 \sigma)$. The apatite track length distribution is unimodal, relatively narrow and negatively skewed (Skewness $=-1.66$ ) with a mean track length of $13.66 \pm 0.17 \mu \mathrm{m}$ and a standard deviation of $1.98 \mu \mathrm{m}$ (Fig. 12). Its Dpar is $1.58 \mu \mathrm{m}$.

Duplicate (U-Th)/He ages of $44.7 \pm 3.7$ and $44.0 \pm 4.2$ Ma were obtained on the same apatite sample from the Dos Amigos porphyry (KP-14), attesting to analytical reproducibility.

\subsection{Discussion}

The U-Pb zircon ages are interpreted as crystallization ages for the intrusions considering that zircon has the highest known closure temperature for $\mathrm{Pb}$ diffusion, which exceeds $900^{\circ} \mathrm{C}$ for zircons of typical sizes (Cherniak and Watson, 2000 and references therein). Thus two thermal events have occurred related to the emplacement of intrusive bodies; the Dos Amigos and Tricolor porphyry stocks of the Domeyko alteration zone crystallized during the Albian (between 108.5 \pm 3.4 and 104.0 $\pm 3.5 \mathrm{Ma}$ ), and the neighboring, unaltered Cachiyuyo Batholith crystallized later, during the Cenomanian between $99.6 \pm 1.8$ and $99.1 \pm 1.9 \mathrm{Ma}$, thereby confirming geological relationships.

The ${ }^{40} \mathrm{Ar} /{ }^{39} \mathrm{Ar}$ data for hydrothermal micas indicate a minimum Late Cretaceous age for hydrother-

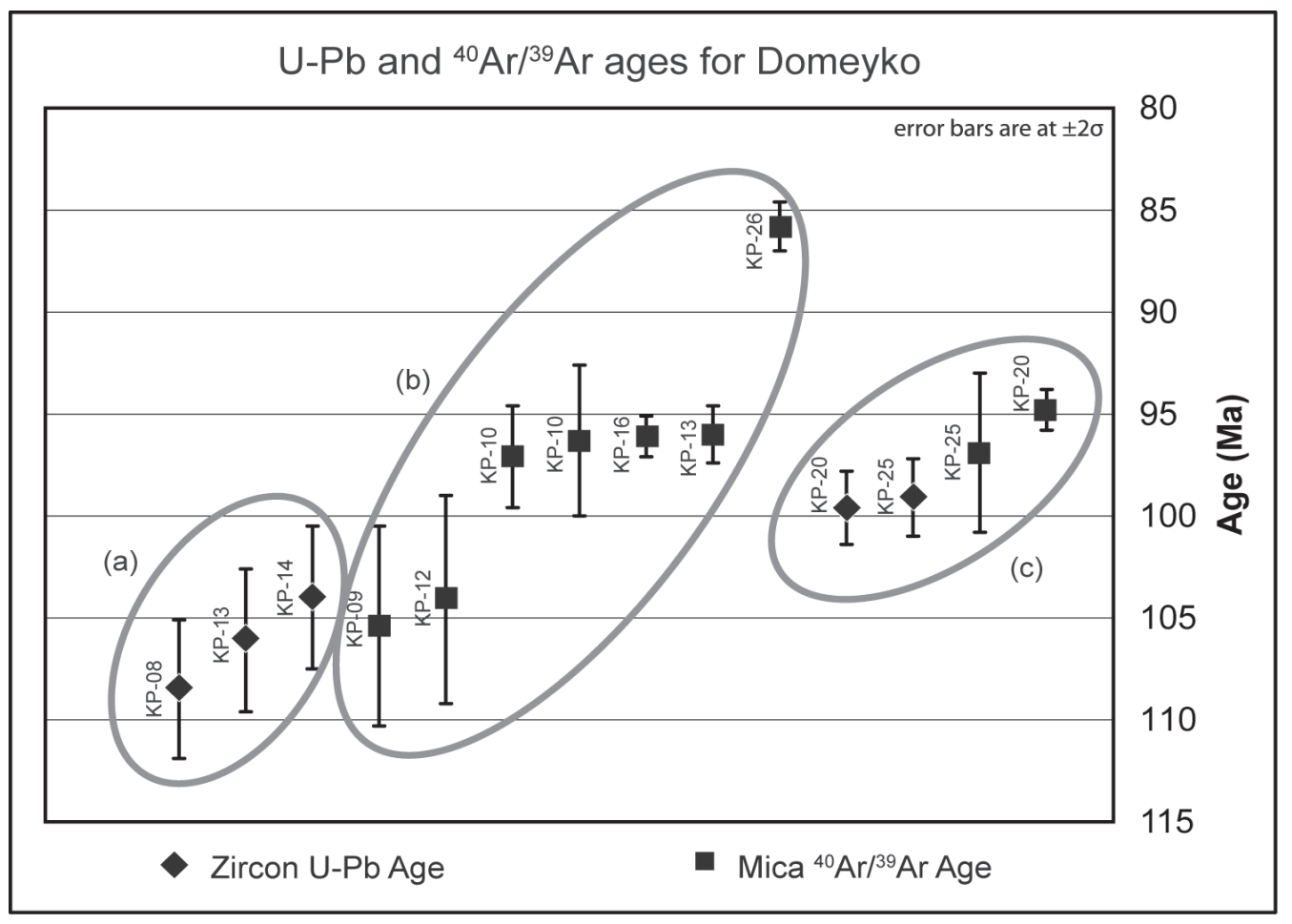

FIG. 11. Summary graph of the geochronological data for the Domeyko Alteration Zone and the neighboring Cachiyuyo Batholith, with sample identification labels: a. crystallization U-Pb zircon ages for the Dos Amigos and Tricolor porphyries; $\mathbf{b} .{ }^{40} \mathrm{Ar} r{ }^{39} \mathrm{Ar}$ ages for micas from the Domeyko alteration zone; note that despite disturbance, reflected by large error bars, most ages coincide within error with $\mathrm{U}-\mathrm{Pb}$ ages for the batholith; c. crystallization $\mathrm{U}-\mathrm{Pb}$ and ${ }^{40} \mathrm{Ar} /{ }^{39} \mathrm{Ar}$ cooling ages for the unaltered Cachiyuyo Batholith. 


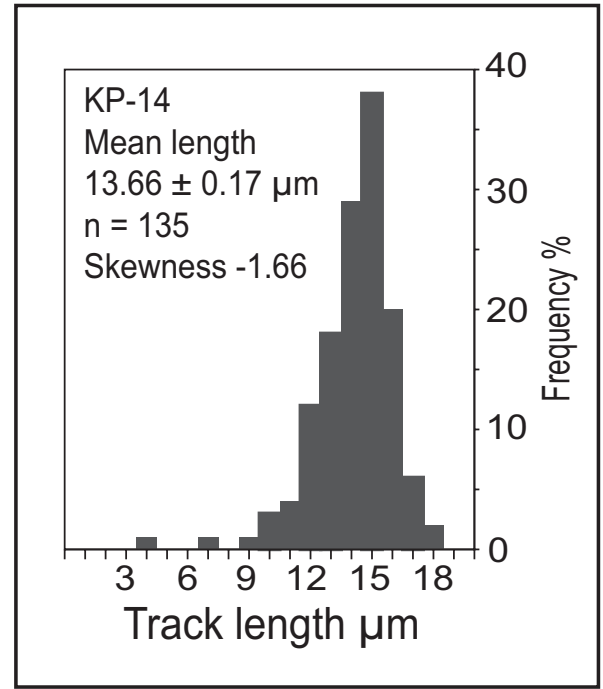

FIG. 12. Histogram showing the distribution of track lengths of apatite sample KP-14 from the Dos Amigos porphyry. The negatively skewed, unimodal distribution of track lengths is compatible with a simple monotonic cooling of the apatite through the temperature range of the apatite partial annealing zone $\left(\sim 125-60^{\circ} \mathrm{C}\right)$.

mal activity in the Domeyko alteration zone, but the disparity and/or imprecision of the ${ }^{40} \mathrm{Ar} /{ }^{39} \mathrm{Ar}$ ages precludes a more accurate age determination. These micas may have been formed during cooling of the porphyry stocks and/or later, during the cooling stage of the neighboring Cachiyuyo Batholith (Fig. 11). Nevertheless, despite disturbance, most ${ }^{40} \mathrm{Ar} /{ }^{39} \mathrm{Ar}$ ages for alteration micas coincide within error limits of the $\mathrm{U}-\mathrm{Pb}$ ages, especially those obtained for the batholith (Fig. 11), indicating that these ${ }^{40} \mathrm{Ar} /{ }^{39} \mathrm{Ar}$ ages record cooling of the Cachiyuyo Batholith. Thus, the thermal event related to the emplacement of the Cachiyuyo Batholith is inferred to have partially or completely reset the isotopic clock of the hydrothermal alteration micas in the adjacent Domeyko Alteration zone.

The crystallization ages obtained for the Dos Amigos porphyry of the Domeyko alteration zone are comparable with the whole rock K-Ar age of 104 \pm 3 Ma reported by Reyes (1991) for sericitized porphyry of the Andacollo copper-gold porphyry deposit and with a U-Pb zircon age of 104.0 $\pm 3.3 \mathrm{Ma}$ for the altered Culebrón porphyry stock located in the center of the Andacollo deposit (our unpublished data). These ages confirm that both deposits are part of the same regional mid-Cretaceous porphyry copper mineralization episode.
The apatite fission-track age of $59.8 \pm 9.8 \mathrm{Ma}$ $( \pm 2 \sigma)$ for the Dos Amigos porphyry is significantly younger than the $\mathrm{U}-\mathrm{Pb}$ and ${ }^{40} \mathrm{Ar} /{ }^{39} \mathrm{Ar}$ ages of 104.0 $\pm 3.5 \mathrm{Ma}$ and 96.0 $\pm 1.4 \mathrm{Ma}$ obtained for this mineralized intrusion, respectively. In addition, the track length distribution (Fig. 12) is comparable to the typical track length distribution of 'undisturbed basement' (Gleadow et al., 1986; Green et al., 1989), which normally results from a progressive monotonic cooling through the temperature range of the apatite partial annealing zone $\left(\sim 125-60^{\circ} \mathrm{C}\right.$; Laslett et al., 1987; Reiners et al., 2005). It is apparent that cooling through the $\sim 125-60^{\circ} \mathrm{C}$ temperature range occurred considerably later than the igneous and hydrothermal thermal events detected in the Domeyko alteration zone, which is consistent with the apatite fission-track age record of exhumation-cooling. Assuming a present-day temperature of $15^{\circ} \mathrm{C}$, a model time-temperature path was generated from the fission-track data of the FT-14 apatite sample using the AFTSolve multi-kinetic inverse modeling software (Ketcham et al., 2000). According to this model the apatite sample started to accumulate tracks at $62.6 \pm 10.2$ $\mathrm{Ma}$ and progressively cooled with time through the temperature range of the apatite partial annealing zone (APAZ: $\sim 125^{\circ}$ to $60^{\circ} \mathrm{C}$ ) during the Paleocene (Fig. 13). Therefore it is inferred that the Dos Amigos porphyry cooled through the $\sim 125$ $60^{\circ} \mathrm{C}$ temperature range during the Paleocene in response to exhumation.

The apatite (U-Th)/He age of $44.7 \pm 3.7 \mathrm{Ma}$ provides further support to the above interpretation considering the even lower temperature range of the apatite He partial retention zone $\left(\sim 85-40^{\circ} \mathrm{C}\right.$; Wolf et al., 1998; Shuster et al., 2006). The apatite cooled through the $\sim 85-40^{\circ} \mathrm{C}$ temperature range during the Eocene, which is coherent with the modeled cooling path from the apatite fission-track data for the Dos Amigos porphyry (Fig. 13). Thus the combined fission-track and (U-Th)/He thermochronological data indicate that the Dos Amigos porphyry was exhumed during the Paleocene-Eocene period. The exhumation during this time probably was an effect of denudation, which in turn could be consequence of surface uplift and erosion, resulting from major tectonic compressive events in northern Chile, such as the ' $\mathrm{K}-\mathrm{T}$ ' tectonic event near the CretaceousTertiary boundary in the region (Cornejo et al., 2003; Charrier et al., 2007) and the important Eocene Incaic compressive tectonism that affected 


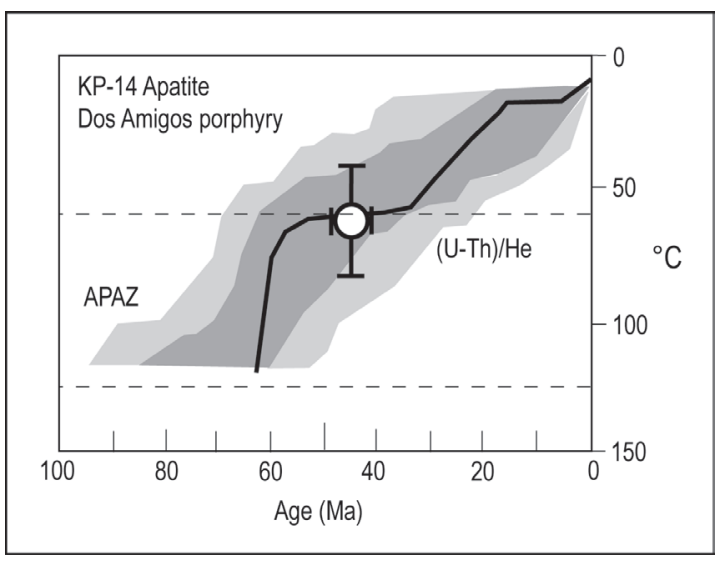

FIG. 13. Time-temperature model of the low temperature cooling history using the fission track data of the apatite sample KP-14 from the Dos Amigos porphyry (AFTSolve best fit line and dark and light gray shading of good and acceptable fit solutions are shown; see text for discussion). The temperature range of the apatite partial annealing zone (APAZ) is indicated by dashed lines. As a reference, the (U-Th)/He age obtained for the same sample is inserted with $\pm 2 \sigma$ error bars; its vertical bars show the temperature range of the apatite He retention zone.

northern Chile and Peru (Charrier and Vicente, 1972; Maksaev, 1978, 1979).

The exhumation cooling of the Dos Amigos porphyry stock through the apatite He partial retention zone $\left(\sim 85-40^{\circ} \mathrm{C}\right.$; Wolf et al., 1998) at $44.7 \pm 3.7 \mathrm{Ma}$ additionally signifies that a maximum of some 2 $\mathrm{km}$ of rock cover may have been removed during the last $44 \mathrm{Myr}$, accepting a geothermal gradient of $30^{\circ} \mathrm{C} / \mathrm{km}$. Although the actual paleogeothermal gradient is uncertain, this implies a very low mean exhumation rate since the mid-Eocene $(<0.05$ $\mathrm{mm} / \mathrm{yr}$ ). Furthermore, the apatite (U-Th)/He age of $44.7 \pm 3.7 \mathrm{Ma}$ also provides a maximum age for the formation of the supergene enrichment blanket at Dos Amigos, because the porphyry had to be exhumed to expose sulfides to the effects of oxidative weathering and chalcocite precipitation within the zone of cool groundwater at the time.

The chalcocite blanket at Dos Amigos, located between 740 and $800 \mathrm{~m}$ elevation probably developed beneath a low hill within the Miocene Atacama pediplain at roughly the same time as the enrichment at Andacollo (e.g., Sillitoe, 2005), considering that terrace relics of the Miocene Atacama Gravels partly surround the Domeyko alteration zone and slope gently westwards from $950 \mathrm{~m}$ to $780 \mathrm{~m}$ above sea level.

\section{Conclusions}

The tonalitic to granodioritic porphyry stocks of Dos Amigos and Tricolor in the Domeyko alteration zone crystallized during the Albian ( $\mathrm{U}-\mathrm{Pb}$ ages from $108.5 \pm 3.4$ to $104.0 \pm 3.5 \mathrm{Ma}$ ). Hydrothermal alteration of the types: potassic, sericitic, kaolinite-illite and propylitic are zoned around these stocks, and stockwork copper mineralization is fundamentally restricted to these porphyries. Therefore the data confirm that these porphyry copper centers are part of the regional, mid-Cretaceous porphyry copper mineralization episode recognized along the eastern part of the Coastal Cordillera of northern Chile, and with identical U-Pb ages as the Culebrón porphyry of the Andacollo copper-gold deposit.

The Cachiyuyo Batholith that marks the western border of the Domeyko alteration zone crystallized later during the Cenomanian (U-Pb ages 99.1 \pm 1.9 and $99.6 \pm 1.8 \mathrm{Ma})$. Most of ${ }^{40} \mathrm{Ar} /{ }^{39} \mathrm{Ar}$ ages obtained for hydrothermal biotite and sericite from the Tricolor and Dos Amigos porphyry centers overlap with the U-Pb ages obtained for the batholith. They establish a minimum Late Cretaceous age for hydrothermal activity, even though it is inferred that they reflect the effect of the thermal overprint imposed by post-mineralization batholith emplacement.

The apatite fission-track and (U-Th)/He thermochronological data are compatible with exhumation-cooling of the Dos Amigos porphyry during the Paleocene-Eocene, probably related to denudation resulting from uplift imposed by the K-T and Incaic compressive tectonism. Furthermore, the apatite (U-Th)/He age of $44.7 \pm 3.7$ Ma provides a maximum age for the supergene enrichment processes that formed the chalcocite blanket of this porphyry system, but also implies a very low mean exhumation rate of the porphyry since the late Eocene.

\section{Acknowledgments}

Conicyt, Chile, through Fondecyt Grant 1040492 to V. Maksaev and F. Munizaga, provided financial support for this study. The investigation of the Domeyko zone was part of the M.Sc. Thesis of A. Almonacid. The CEMIN mining company granted access to the Dos Amigos mine; we are particularly thankful to D. Ibaceta, Mine Manager; Mr. L. Castro, Mine Administrator, and to Mr. A. Álvarez, Mine Supervisor. Reviews by J. Perelló, R.J. Pankhurst, 
and R.H. Sillitoe contributed to improve this paper; a previous version also benefited from evaluations by K. Hickey and an anonymous reviewer.

\section{References}

Almonacid, A. 2007. Geología de la zona de alteración de Domeyko y del yacimiento de cobre Dos Amigos, Región de Atacama, Chile. M.Sc. Thesis (Unpublished), Universidad de Chile, Departamento de Geología: p 114.

Arabasz, W.J. 1971. Geological and geophysical studies of the Atacama Fault Zone in Northern Chile. Ph.D. Thesis (Unpublished), Californian Institute of Technology: 264 p. Pasadena, California, U.S.A.

Arévalo, C. 2005a. Carta Copiapó, Región de Atacama. Servicio Nacional de Geología y Minería, Carta Geológica de Chile, Serie Geología Básica 91: 54 p., escala 1:100.000.

Arévalo, C. 2005b. Carta Los Loros, Región de Atacama. Servicio Nacional de Geología y Minería, Carta Geológica de Chile, Serie Geología Básica 92: 54 p., escala 1:100.000.

Arévalo, C.; Mourgues, F.A.; Jaillard, E.; Bulot, L.G. 2005. Comparative evolution of the Lower Cretaceous Pluto-volcanic arc and back-arc from the Atacama Region, Chile. In International Symposium on Andean Geodynamics (ISAG), No. 6, Extended Abstracts: 57-60. Barcelona.

Arévalo, C.; Grocott, J.; Martin, W.; Pringle, M.; Taylor, G. 2006. Structural setting of the Candelaria Fe oxide $\mathrm{Cu}-\mathrm{Au}$ deposit, Chilean Andes (27³0’S). Economic Geology 101: 819-841.

Boric, R.; Díaz, F.; Maksaev, V. 1990. Geología y yacimientos metalíferos de la Región de Antofagasta, Servicio Nacional de Geología y Minería, Boletín 40: p 246.

Bourgois, J.; Toussaint, J.F.; González, H.; Azema, J.; Calle, B.; Desmet, A.; Murcia, L.; Acevedo, A.; Parra, E.; Tournon, J. 1987. Geological history of the Cretaceous ophiolitic complexes in northwestern South America (Colombian Andes). Tectonophysics 143: 307-327.

Brown, M.; Díaz, F.; Grocott, J. 1993. Displacement history of the Atacama fault system $25^{\circ} 00^{\prime} \mathrm{S}-27^{\circ} 00^{\prime} \mathrm{S}$, northern Chile. Geological Society of America Bulletin 105: 1165-1174.

Camus, F. 2002. The Andean porphyry systems. In Giant Ore Deposits: Characterisitics, genesis and exploration. (Cooke, D.R.; Pongratz, J.; editors). CODES, Special Publication 4: 5-21. Tasmania, Australia.
Camus, F. 2003. Geología de los sistemas porfíricos en los Andes de Chile. Servicio Nacional de Geología y Minería: 267 p. Chile.

Carlson, W.D.; Donelick, R.A.; Ketcham, R.A. 1999. Variability of apatite fission-track annealing kinetics: I Experimental results. American Mineralogist 34: 1213-1223.

Charrier, R.; Vicente, J.-C. 1972. Liminary and geosyncline Andes: major orogenic phases and synchronical evolutions of the central and Magellan sectors of the Argentine Chilean Andes. Solid Earth Problems Conference, Upper Mantle Project 2: 451-70. Buenos Aires.

Charrier, R.; Pinto, L.; Rodríguez, M.P. 2007. Tectonostatigraphic evolution of the Andean Orogen in Chile. In The Geology of Chile (Moreno, T.; Gibbons, W.; editors). The Geological Society: 21-114. London.

Cherniak, D.J.; Watson, E.B. 2000. Pb diffusion in zircon. Chemical Geology 172: 5-24.

Cornejo, P.; Matthews, S.; Pérez, C. 2003. The 'K-T' compressive deformation event in northern Chile ( $24^{\circ}$ $27^{\circ} \mathrm{S}$ ). Proceeedings. In Congreso Geológico Chileno, No. 10, Actas, CD-ROM. Concepción.

Dallmeyer, R.D.; Brown, M.; Grocott, J.; Taylor, G.K.; Treolar, P.J. 1996. Mesozoic magmatic and tectonic events within the Andean plate boundary zone, $26^{\circ}$ $27^{\circ} 30^{\prime} \mathrm{S}$, North Chile: constraints from ${ }^{40} \mathrm{Ar} /{ }^{39} \mathrm{Ar}$ mineral ages. The Journal of Geology 104: 19-40.

Dalrymple, G.B.; Lanphere, M.A. 1971. ${ }^{40} \mathrm{Ar} /{ }^{39} \mathrm{Ar}$ technique of $\mathrm{K}-$ Ar dating: A comparison with the conventional technique. Earth and Planetary Science Letters, 12: 300-308.

Dalziel, I.W.D. 1986. Collision and Cordilleran orogenesis: An Andean perspective. In Collisional on Tectonics (Coward, M.P.; Ries, A.C.; editors). Geological Society of London Special Publication 19: 389-404. London.

Díaz, A.; Vivallo, W.; Jorquera, R.; Pizarro, N. 2003. Depósitos de $\mathrm{Fe}$, óxidos de $\mathrm{Fe}-\mathrm{Cu}-\mathrm{Au}$ y su relación con el magmatismo del Cretácico Inferior, III Región de Atacama, Chile. In Congreso Geológico Chileno, No. 10, Actas, CD-ROM. Concepción.

Donelick, R.A.; Ketcham, R.A.; Carlson, W.D. 1999. Variability of apatite fission track annealing kinetics II: Crystallographic orientation effects. American Mineralogist 84: 301-307.

Donelick, R.A.; O’Sullivan, P.B.; Ketcham, R.A. 2005. Apatite fission track analysis. In Low Temperature Thermochronology: Techniques, Interpretations, and Applications (Reiners, P.W.; Ehlers, T.A.; edi- 
tors). Reviews in Mineralogy and Geochemistry 58: 49-94.

Espinoza, S. 1990. The Atacama-Coquimbo Ferriferous Belt, Northern Chile. In Stratabound Ore Deposits in the Andes (Fontboté, L.; Amstutz, G.C.; Cardozo, M.; Cedillo, E.; Frutos, J.; editors). Springer-Verlag: 353-364. Berlin.

Farley, K.A.; Wolf, R.A.; Silver, L.T. 1996. The effects of long alpha-stopping distances on (U-Th)/He ages. Geochimica et Cosmochimica Acta 60: 4223-4229.

Farley, K.A. 2002.(U-Th)/He dating: Techniques, calibrations, and applications. Reviews in Mineralogy and Geochemistry 47: 819-844.

Fleck, R.J.; Sutter, J.F.; Elliot, D.H. 1977. Interpretation of discordant ${ }^{40} \mathrm{Ar} /{ }^{39} \mathrm{Ar}$ spectra of Mesozoic tholeiites from Abtarctica. Geochimica et Cosmochimica Acta 41: 15-32.

Gehrels, G.E.; Valencia, V.A.; Ruiz, J. 2008. Enhanced precision, accuracy, efficiency, and spatial resolution of $\mathrm{U}-\mathrm{Pb}$ ages by laser ablation-multicollectorinductively coupled plasma-mass spectrometry. Geochemistry, Geophysics, and Geosystems 9: Q03017, doi:10.1029/2007GC001805

Gelcich, S.H.; Davis, D.W.; Spooner, E.T.C. 2003. New $\mathrm{U}-\mathrm{Pb}$ ages for host rocks, mineralization and alteration of iron oxide $(\mathrm{Cu}-\mathrm{Au})$ deposits in the Coastal Cordillera of northern Chile. In South American Symposium on Isotope Geology, No. 4: 63-66. Salvador de Bahia, Brazil.

Gelcich, S.; Davis, D.W.; Spooner, E.T.C. 2005. Testing the apatite-magnetite geochronometer: $\mathrm{U}-\mathrm{Pb}$ and ${ }^{40} \mathrm{Ar} /{ }^{39} \mathrm{Ar}$ geochronology of plutonic rocks, massive magnetiteapatite tabular bodies, and IOCG mineralization in Northern Chile. Geochimica et Cosmochimica Acta 69 (13): 3367-3384

Gleadow, A.J.W.; Duddy, I.R.; Green, P.F.; Lovering, J.F. 1986. Confined fission track lengths in apatite: a diagnostic tool for thermal history analysis. Contributions to Mineralogy and Petrology 94: 405-415.

Green, P.F.; Duddy, I.R.; Laslett, G.M.; Hegarty, K.A.; Gleadow, A.J.W.; Lovering, J.F. 1989. Thermal annealing techniques of fission tracks in apatite 4 Quantitative modelling techniques and extension to geological timescales. Chemical Geology (Isotope Geoscience Section) 79: 155-182.

Grocott, J.; Taylor, G.K. 2002. Magmatic arc fault systems, deformation partitioning and emplacement of granitic complexes in the Coastal Cordillera, north Chilean Andes (25 $30^{\circ}$ 'S to $\left.27^{\circ} 00^{\prime} \mathrm{S}\right)$. Journal of the Geological Society of London 159: 425-442.
Hasebe, N.; Barbarand, J.; Jarvis, K.; Carter, A.; Hurford, A.J. 2004. Apatite fission-track chronometry using laser ablation ICP-MS. Chemical Geology 207: 135-145.

Ketcham, R.A.; Donelick, R.A.; Carlson, W.D. 1999. Variability of apatite fission track annealing kinetics III: Extrapolations to geological time scales, American Mineralogist 84: 1235-1255.

Ketcham, R.A.; Donelick, R.A.; Donelick, M.B. 2000. AFTSolve: A program for multi-kinetic modeling of apatite fission-track data. Geological Materials Research 2 (electronic www-based journal of the Mineralogical Society of America).

Laslett, G.M.; Green, P.F.; Duddy, I.R.; Gleadow, A.J.W. 1987. Thermal annealing of fission tracks in apatite 2: A quantitative analysis. Chemical Geology 65: 1-15.

Llaumett, C. 1975. Faja Pacífica de cobres porfíricos y desarrollos de alteración hidrotermal de Chile. In Congreso Iberoamericano de Geología Económica, No. 2, Actas 2: 331-348. Buenos Aires.

Llaumett, C.; Olcay, L.; Marín, C.; Marquardt, J.C.; Reyes, E. 1975. El yacimiento de cobre porfídico Andacollo, provincia de Coquimbo, Chile. Revista Geológica de Chile 2: 56-66.

Maksaev, V. 1978. Cuadrángulo Chitigua y sector oriental del Cuadrángulo Cerro Palpana, Región de Antofagasta. Instituto de Investigaciones Geológicas, Carta Geológica de Chile 31: 55 p., escala 1:50.000.

Maksaev, V. 1979. Las Fases Tectónicas Incaica y Quechua en la Cordillera de los Andes del Norte Grande de Chile. In Congreso Geológico Chileno, No. 2, Actas 1: B63 B77. Arica.

Maksaev, V.; Munizaga, F.; Fanning, M.; Palacios, C.; Tapia, J. 2006a. SHRIMPU-Pb dating of the Antucoya porphyry copper deposit: new evidence for an Early Cretaceous porphyry-related metallogenic epoch in the Coastal Cordillera of northern Chile. Mineralium Deposita 41 (7): 637-644.

Maksaev, V.; Munizaga, F.; Valencia, V.; Barra, F.; McWilliams, M.; Mathur, R. 2006b. Geochronology of Cretaceous porphyry copper deposits of the Coastal Cordillera of northern Chile (latitudes $26^{\circ} 30^{\prime}$ to $30^{\circ} 30^{\prime}$ S). Geological Society of America Abstracts with Programs 38 (7): 347.

Maksaev, V.; Townley, B.; Palacios, C.; Camus, F. 2007. Metallic ore deposits. In The Geology of Chile (Moreno, T.; Gibbons, W.; editors). The Geological Society, London: 179-199. London.

Maksaev, V.; Munizaga, F.; Valencia, V.; Barra, F. 2009. 
LA-ICP-MS zircon U-Pb geochronology to constrain the age of post-Neocomian continental deposits of the Cerrillos Formation, Atacama Region, northern Chile: tectonic and metallogenic implications. Andean Geology 36 (2):264-287.

Marschik, R.; Fonboté, L. 2001. The Candelaria-Punta del Cobre iron oxide $\mathrm{Cu}-\mathrm{Au}(-\mathrm{Zn}-\mathrm{Ag})$ deposits, Chile. Economic Geology 96: 1799-1826.

Marschik, R.; Söllner, F. 2006. Early Cretaceous U-Pb zircon ages for the Copiapó plutonic complex and implications for the IOCG mineralization at Candelaria, Atacama, Region, Chile. Mineralium Deposita 41: 785-801.

Marsh, T.M.; Einaudi, M.T.; McWilliams, M. 1997. ${ }^{40} \mathrm{Ar} /{ }^{39} \mathrm{Ar}$ geochronology of $\mathrm{Cu}-\mathrm{Au}$ and $\mathrm{Au}-\mathrm{Ag}$ mineralization in the Potrerillos district, Chile. Economic Geology 92: 784-806.

Mathur, R.; Marschik, R.; Ruiz, J.; Munizaga, F.; Leveille, R.A.; Martin, W. 2002. Age of mineralization of the Candelaria $\mathrm{Fe}$ oxide $\mathrm{Cu}-\mathrm{Au}$ deposit and the origin of the Chilean Iron Belt, based on Re-Os isotopes. Economic Geology 97: 59-71.

Mortimer, C. 1973. The Cenozoic history of the southern Atacama Desert, Chile. Journal of the Geological Society of London 129: 505-526.

Moscoso, R.; Nasi, C.; Salinas, P. 1982. Geología de la Hoja Vallenar y parte Norte de la Hoja La Serena. Servicio Nacional de Geología y Minería, Carta Geológica de Chile 55: 100 p. Santiago.

Mpodozis, C.; Ramos, V.A. 1990. The Andes of Chile and Argentina. In Geology of the Andes and its Relation to Hydrocarbon and Energy Resources (Ericksen, G.E.; Cañas, M.T.; Reinemund, J.A.; editors). Circum-Pacific Council for Energy and Hydrothermal Resources. American Association of Petroleum Geologists, Earth Science Series 11: 5990. Houston, Texas.

Munizaga, F.; Huete, C.; Hervé, F. 1985. Geocronología K-Ary razones iniciales ${ }^{87} \mathrm{Sr} /{ }^{86} \mathrm{Sr}$ de la Franja Pacífica de Desarrollos Hidrotermales. In Congreso Geológico Chileno, No. 4, Actas 4: 357-379. Antofagasta.

Nyström, J.O.; Henríquez, F. 1994. Magmatic features of iron ores of the Kiruna type in Chile and Sweden: ore textures and magnetite geochemistry. Economic Geology 89: 820-839.

Oyarzún, R.; Oyarzún, J.; Ménard, J.; Lillo, J. 2003. The Cretaceous Iron Belt of Northen Chile: Role of oceanic plates, a superplume event, and major shear zone. Mineralium Deposita 38: 640-646.

Perelló, J.; Martini, R.; Arcos, R.; Muhr, R. 2003. Buey Muerto: porphyry copper mineralization in the Early
Cretaceous arc of northern Chile. In Congreso Geológico Chileno, No. 10, Actas, CD-ROM. Concepción.

Reiners, P.W.; Ehlers, T.A.; Zeitler, P.K. 2005. Past, present, and future of thermochronology. In Low Temperature Thermochronology: Techniques, Interpretations, and Applications (Reiners, P.W.; Ehlers, T.A.; editors). Reviews in Mineralogy and Geochemistry 58: 1-18.

Reyes, M. 1991. The Andacollo strata-bound gold deposit, Chile, and its position in a porphyry copper-gold system. Economic Geology 86: 1301-1316.

Ruiz, C.; Corvalán, J.; Klohn, C.; Klohn, E.; Levi, B. 1965. Geología y yacimientos metalíferos de Chile. Instituto de Investigaciones Geológicas: 305 p. Santiago.

Scheuber, E.; Andriessen, P.A.M. 1990. The kinematic and geodynamic significance of the Atacama fault zone, northern Chile. Journal of Structural Geology 12: 24-257.

Scheuber, E.; Hammerschmidt, K.; Friedrichsen, H. 1995. ${ }^{40} \mathrm{Ar} /{ }^{39} \mathrm{Ar}$ and $\mathrm{Rb}-\mathrm{Sr}$ analyses from ductile shear zones from the Atacama Fault Zone, Northern Chile: the age of deformation. Tectonophysics 250: 61-87.

Scheuber, E.; González, G. 1999. Tectonics of the Jurassic-Early Cretaceous magmatic arc of the north Chilean Coastal Cordillera $\left(22^{\circ}-26^{\circ} \mathrm{S}\right)$ : a story of crustal deformation along a convergent plate boundary. Tectonics 18: 895-910.

Segerstrom, K.; Parker, R.L. 1959. Cuadrángulo Cerrillos, Provincia de Atacama. Instituto de Investigaciones Geológicas, Carta Geológica de Chile 2: 33 p., escala 1:50.000.

Shuster, D.L.; Flowers, R.M.; Farley, K.A. 2006. The influence of natural radiation damage on helium diffusion kinetics in apatite. Earth and Planetary Science Letters 249: 148-161.

Sillitoe, R.H. 2003. Iron oxide-copper-gold deposits: an Andean view. Mineralium Deposita 38: 787-812.

Sillitoe, R.H. 2005. Supergene oxidized and enriched porphyry copper and related deposits. In Economic Geology One Hundredth Anniversary Volume (Heddenquist, J.W.; Thompson, J.F.H.; Goldfarb, R.J.; Richards, J.P.; editors). Society of Economic Geologists: 723-768. Littleton, Colorado, U.S.A.

Sillitoe, R.H.; Perelló, J. 2005. Andean copper province: tectonomagmatic settings, deposit types, Metallogeny, exploration, and discovery. In Economic Geology One Hundredth Anniversary Volume (Hedenquist, J.W.; Thompson, J.F.H.; Goldfarb, R.; Richards, J.; editors). Society of Economic Geologists: 845-890. Littleton, Colorado, USA. 
Taylor, G.K.; Grocott, J.; Pope, A.; Randall, D.E. 1998. Mesozoic fault systems, deformation and fault block rotation in the Andean forearc; a crustal scale strike-slip duplex in the Coastal Cordillera of northern Chile. Tectonophysics 299: 93-109.

Ullrich, T.D.; Clark, A.H. 1999. The Candelaria copper-gold deposit, Region III, Chile: Paragenesis, geochronology and fluid composition. In Mineral Deposits: Processes to Processing. Balkema: 201204. Rotterdam.

Vila, T.; Lindsay, N.; Zamora, R. 1996. Geology of the
Manto Verde copper deposit, Northern Chile: a specularite-rich, hydrothermal-tectonic breccia related to the Atacama Fault Zone. In Andean copper deposits: new discoveries, mineralization styles and metallogeny (Camus, F.; Sillitoe, R.H.; Petersen, R.; editors). Society of Economic Geologists Special Publication 5: 157-170.

Wolf, R.A.; Farley, K.A.; Kass, D.M. 1998. Modeling of the temperature sensitivity of the apatite (UTh)/He thermochronometer. Chemical Geology 148: 105-114.

Manuscript received: March 12, 2009; revised/accepted: October 16, 2009. 


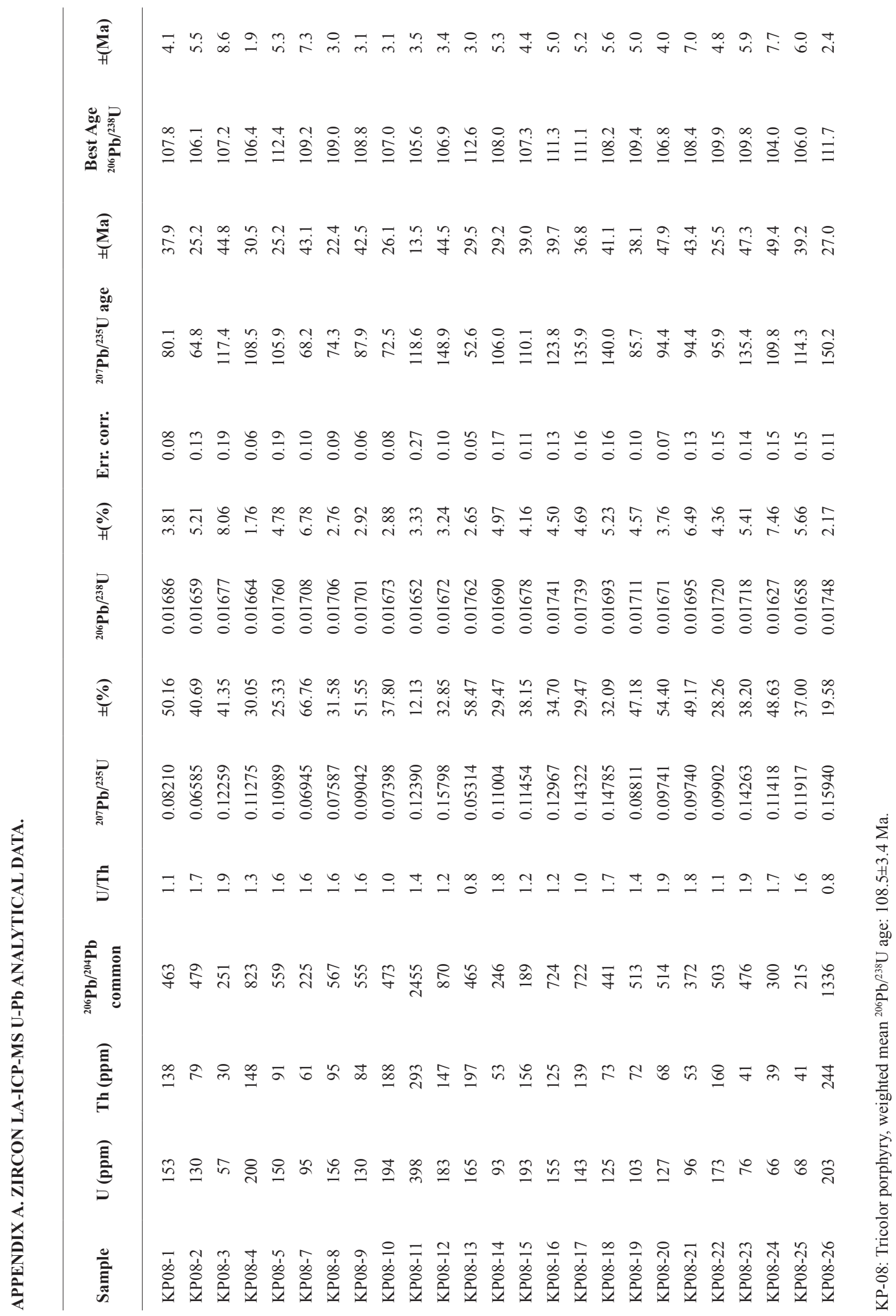




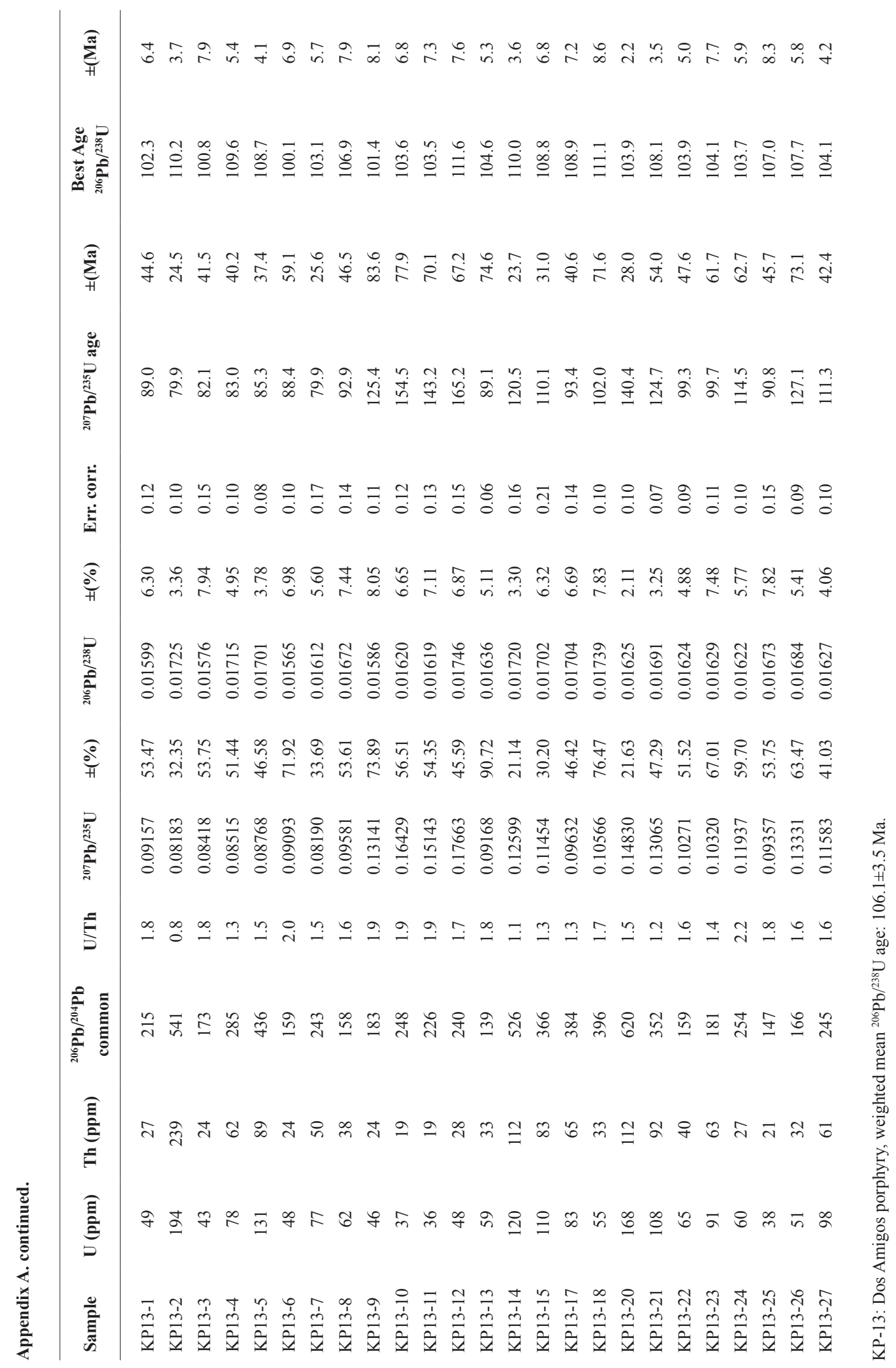




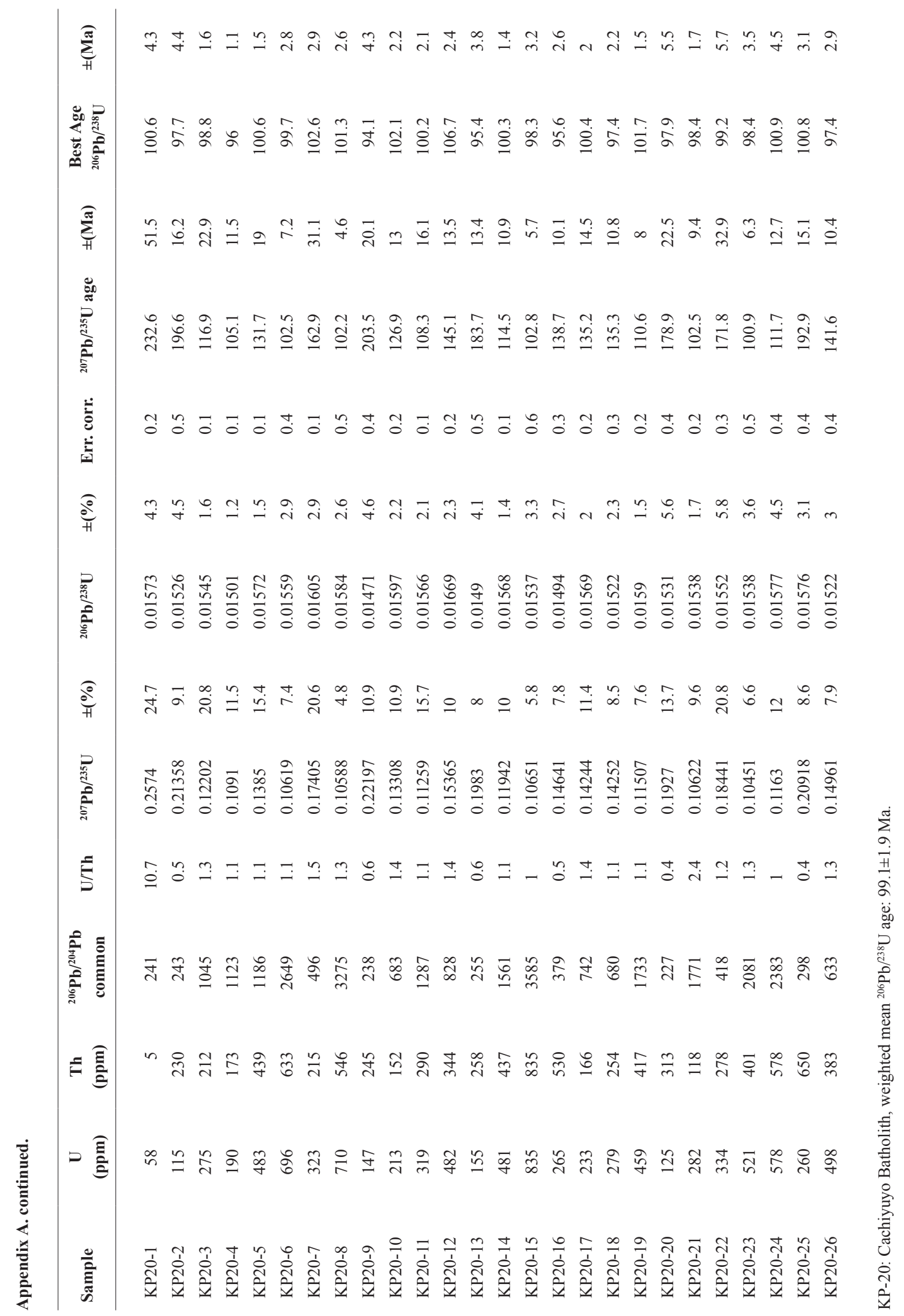




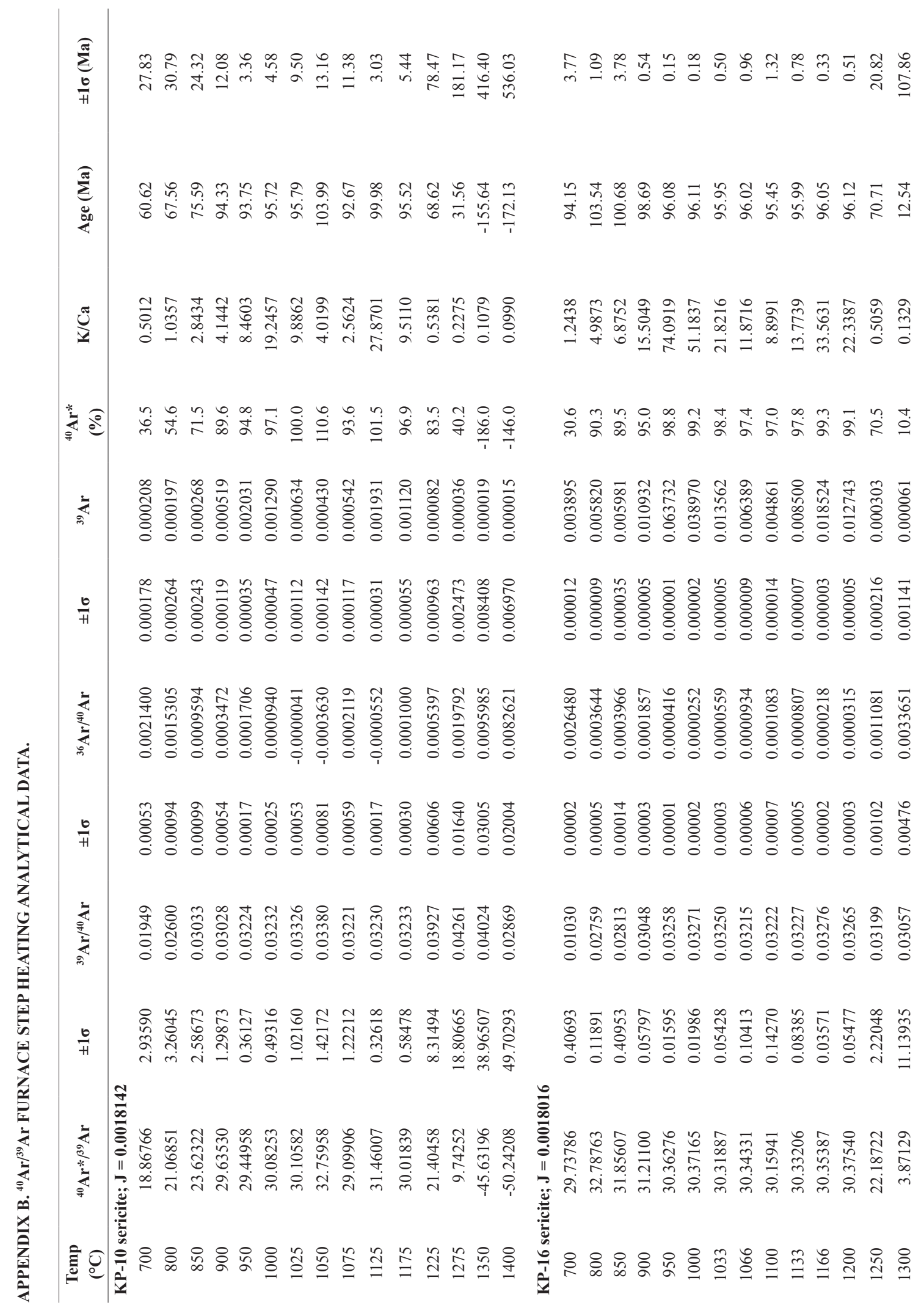




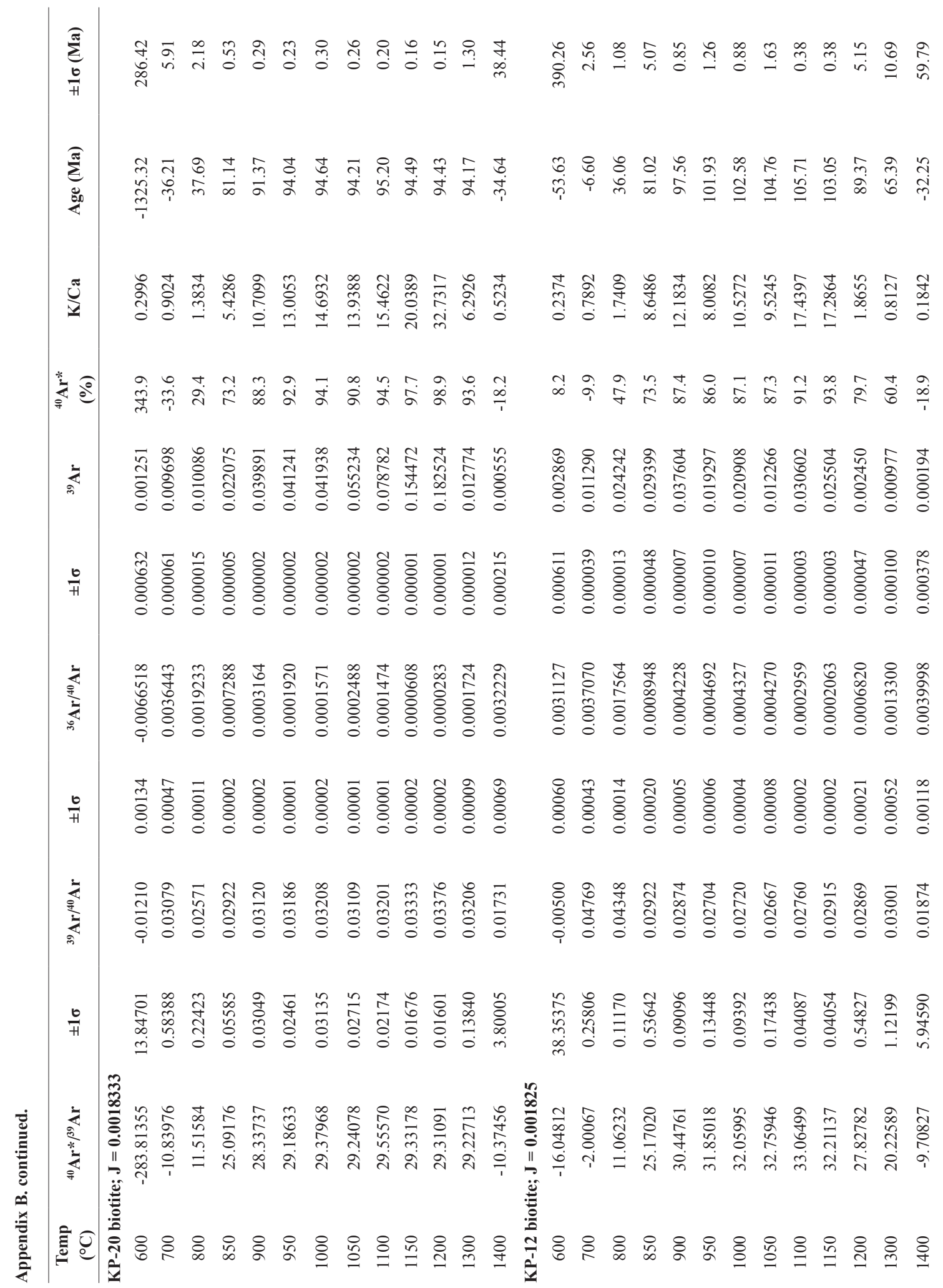




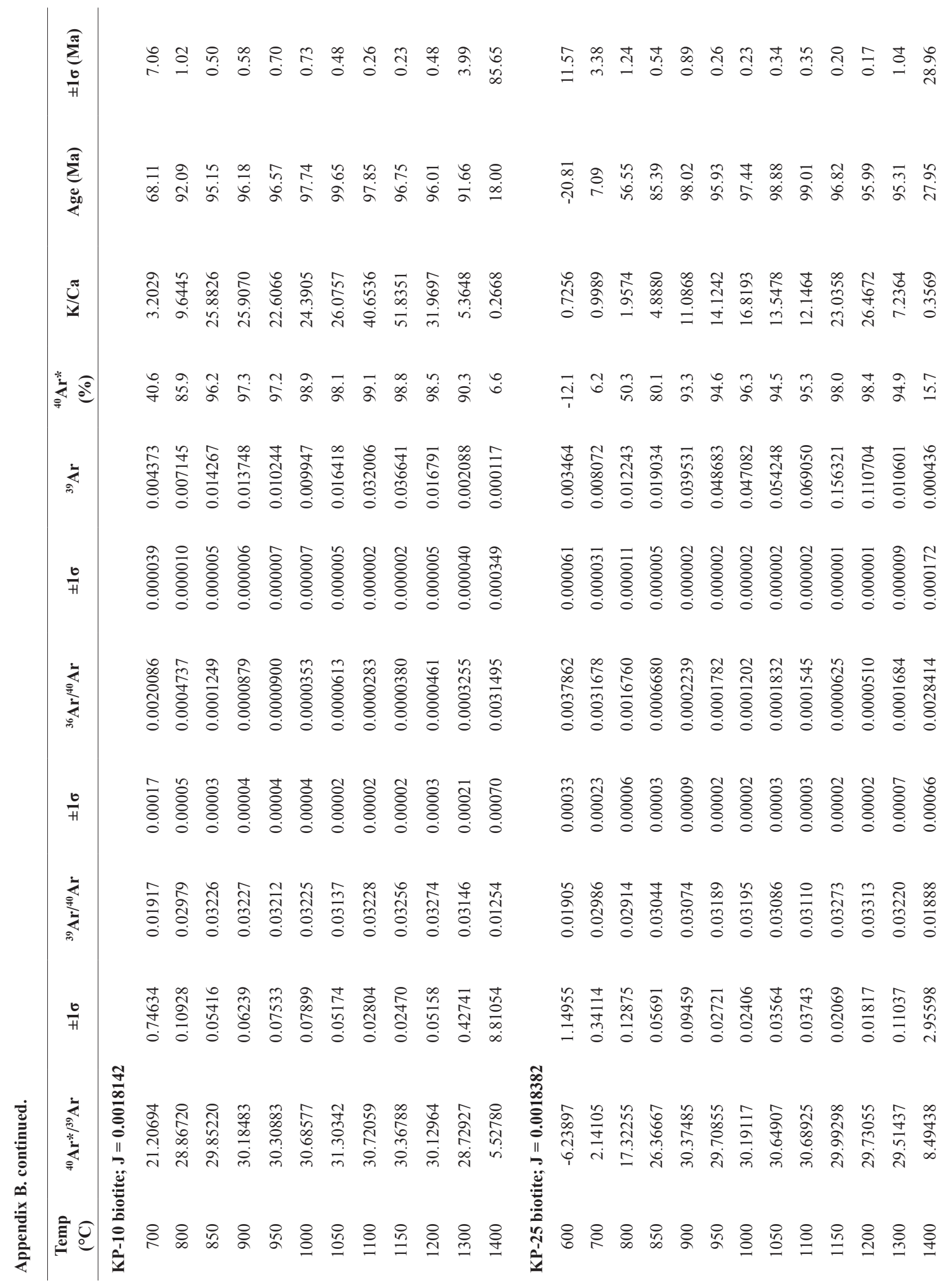




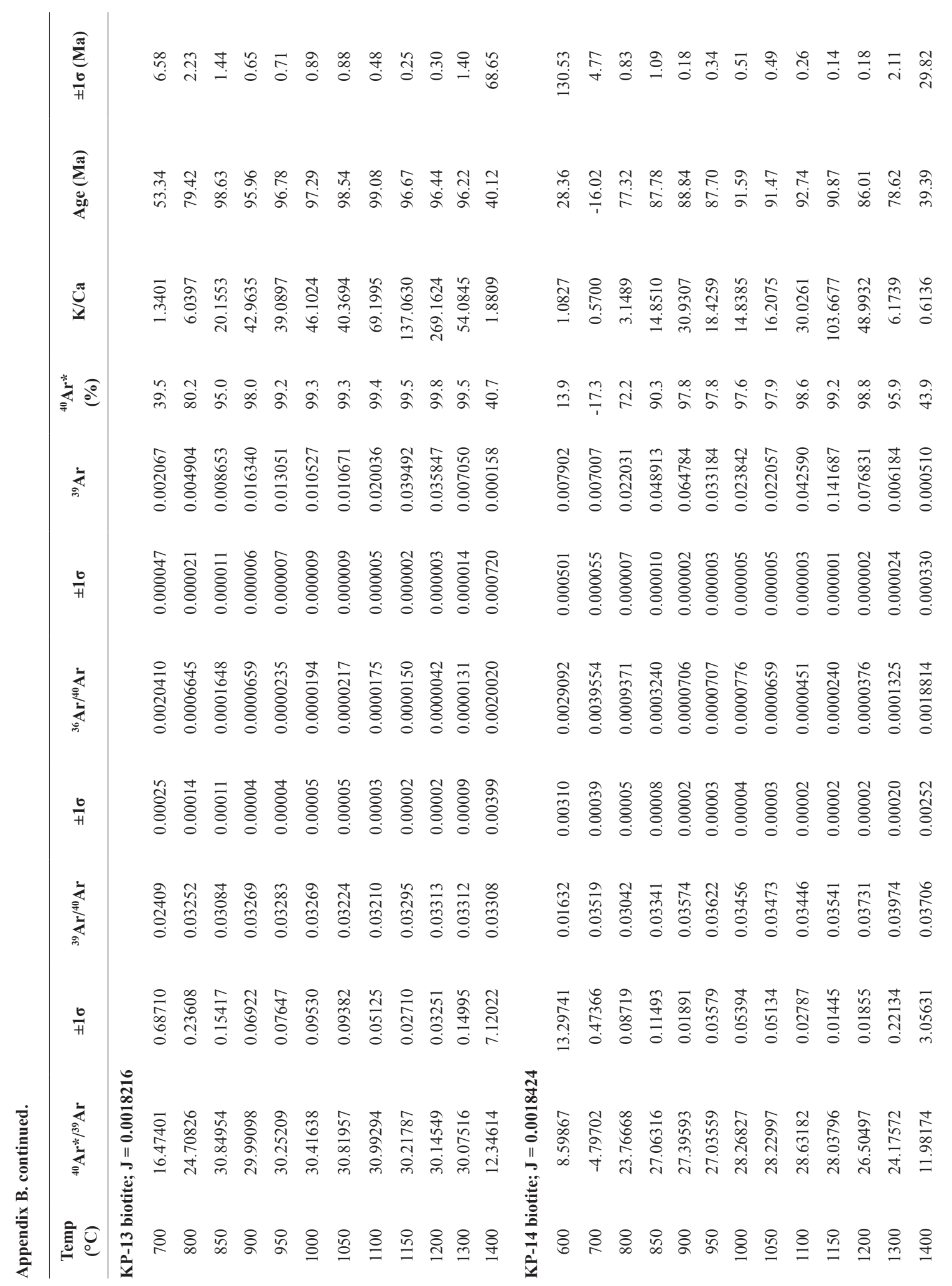




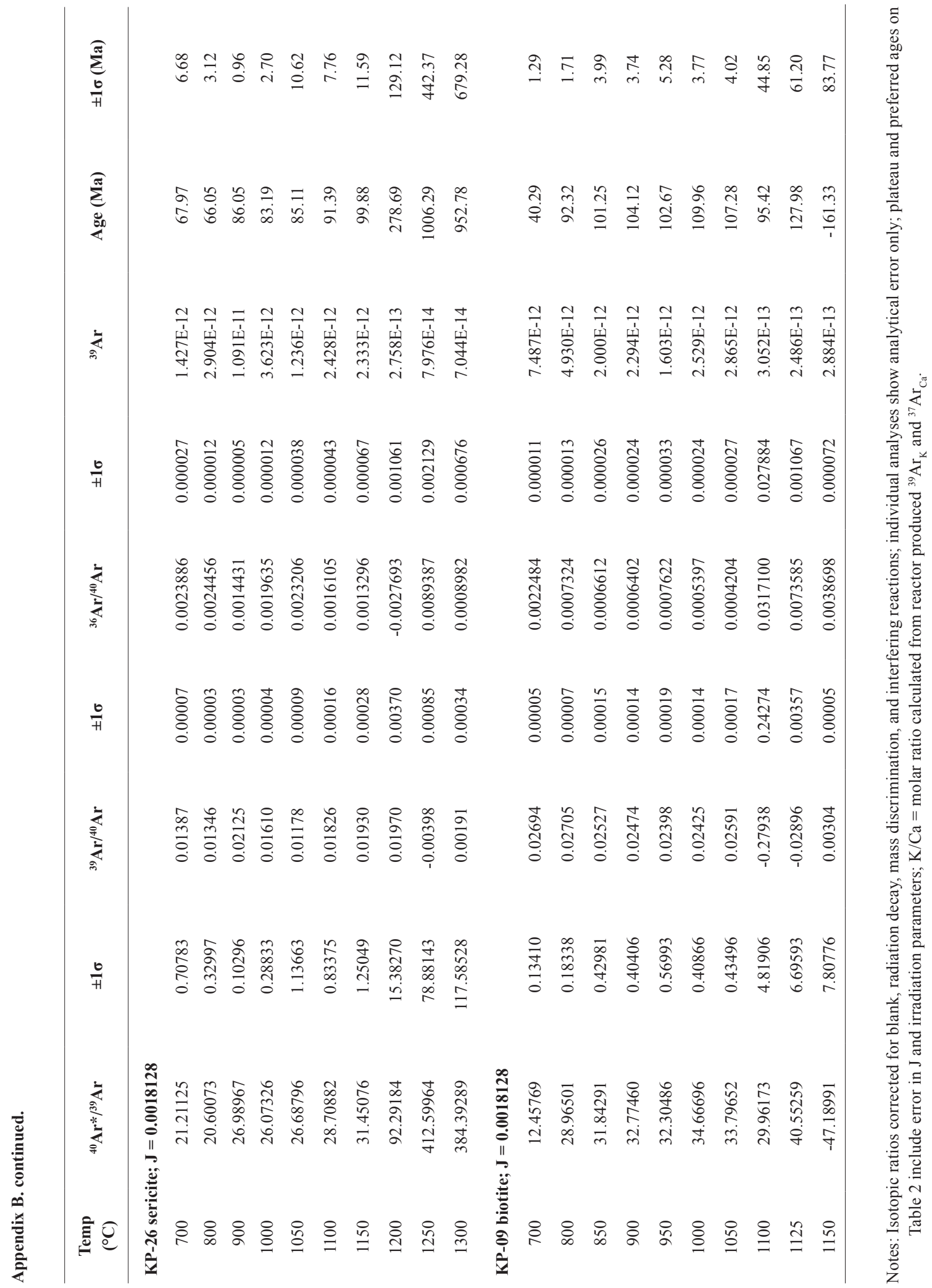




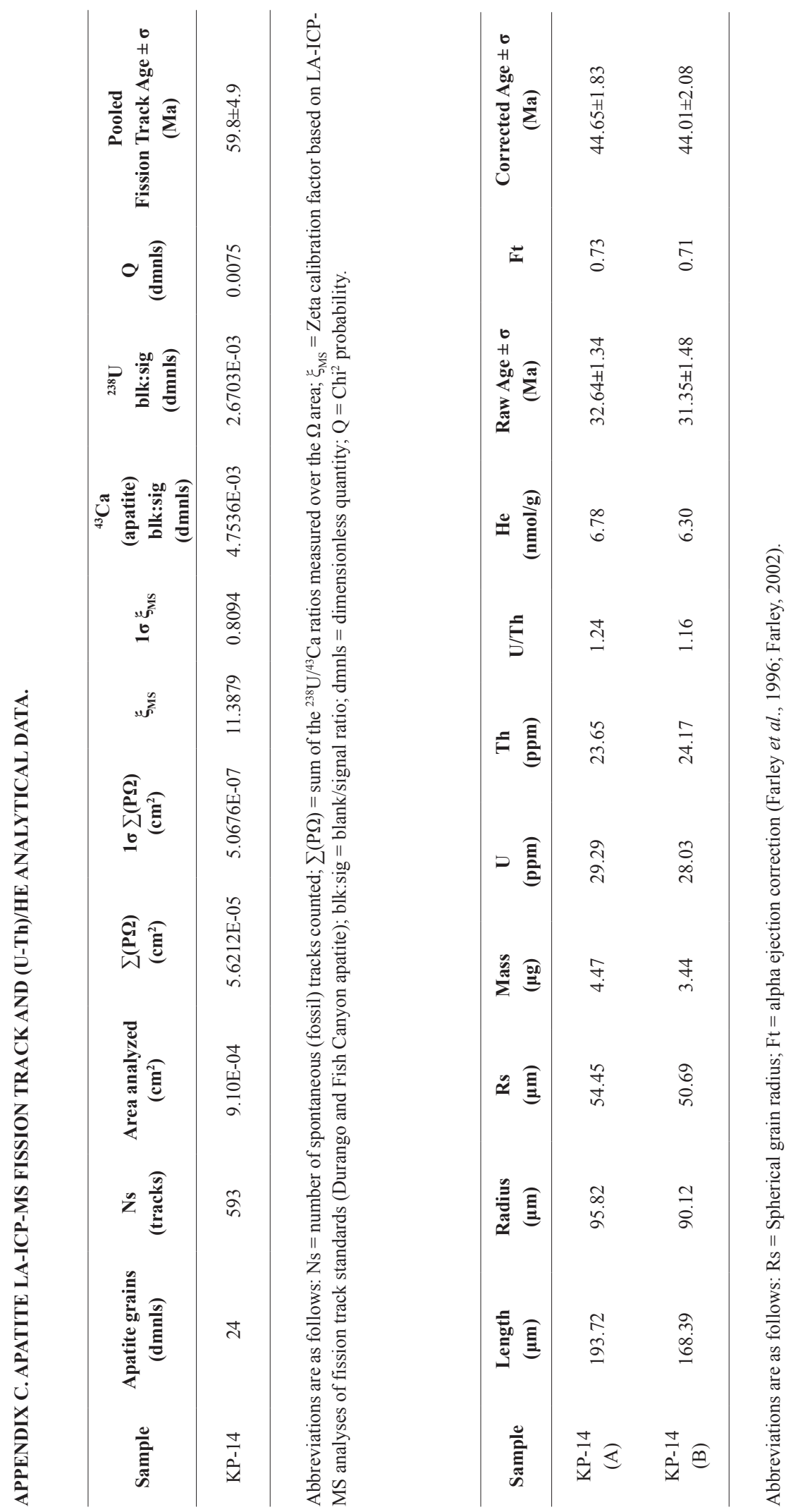

